IZADP No. 1452

Poverty, Inequality, and Growth in Urban China, 1986-2000

Xin Meng

Robert Gregory

Youjuan Wang

J anuary 2005 


\title{
Poverty, Inequality, and Growth in Urban China, 1986-2000
}

\author{
Xin Meng \\ Australian National University \\ Robert Gregory \\ Australian National University \\ and IZA Bonn \\ Youjuan Wang \\ Chinese State Statistical Bureau
}

Discussion Paper No. 1452

January 2005

IZA

P.O. Box 7240

53072 Bonn

Germany

Phone: +49-228-3894-0

Fax: +49-228-3894-180

Email: iza@iza.org

\begin{abstract}
Any opinions expressed here are those of the author(s) and not those of the institute. Research disseminated by IZA may include views on policy, but the institute itself takes no institutional policy positions.

The Institute for the Study of Labor (IZA) in Bonn is a local and virtual international research center and a place of communication between science, politics and business. IZA is an independent nonprofit company supported by Deutsche Post World Net. The center is associated with the University of Bonn and offers a stimulating research environment through its research networks, research support, and visitors and doctoral programs. IZA engages in (i) original and internationally competitive research in all fields of labor economics, (ii) development of policy concepts, and (iii) dissemination of research results and concepts to the interested public.
\end{abstract}

IZA Discussion Papers often represent preliminary work and are circulated to encourage discussion. Citation of such a paper should account for its provisional character. A revised version may be available directly from the author. 


\begin{abstract}
Poverty, Inequality, and Growth in Urban China, 1986-2000*

Although urban China has experienced spectacular income growth over the last two decades, increases in inequality, reduction in social welfare provision, deregulation of grain prices, and increases in income uncertainty in the 1990s have increased urban poverty. Using a large repeated cross-section household survey data from 1986 to 2000, this study maps out the change in income, inequality, and poverty over the 15 year period and investigates the determinants of poverty. It is found that the increase in the poverty rate in the $1990 \mathrm{~s}$ is associated with the increase in the relative food price, and the need to spend on education, housing and medical care which were previously paid by the state. In addition, the increase in the saving rate of the poor due to an increase in income uncertainty contributes significantly to the increase in poverty measured in terms of expenditure. Even though income growth reduces poverty, the radical reform measures implemented in the 1990s have sufficiently offset this gain that urban poverty is higher in 2000 than in 1986.
\end{abstract}

JEL Classification: I31, D31, O40, O15

Keywords: poverty, income growth, inequality, China

Corresponding author:

Xin Meng

Department of Economics

Research School of Pacific and Asian Studies

Australian National University

Canberra 0200

Australia

Email: Xin.Meng@anu.edu.au

\footnotetext{
${ }^{*}$ Financial support from the Australian Research Council is acknowledged.
} 


\section{Introduction}

Although urban China has experienced unprecedented income increases over the last two decades, radical reform measures implemented in the 1990s has increased income inequality, reduced social welfare provision, increased grain prices, and increased income uncertainty. All these factors may have acted as a counter weight to income growth and the net effect on poverty depends on whether income growth or the offsetting factors dominate. ${ }^{1}$

Previous studies on the relationship between economic growth and poverty often use cross country data. The cross-country studies generate two problems. First, they are usually unable to consider in details the institutional and household behavioural details that may affect the change in poverty and economic growth within each country. This should not be a significant problem if the behavioural and institutional changes within each country overtime are minimal. For a transitional economy like China, however, where institutions are changing very fast and households' behaviour is also changing, things are different. If the detailed institutional and behavioural changes are ignored, one may fail to understand and explain the real relationship between growth and poverty.

Second, cross-country data often have a limited number of data points for each country and the results, therefore, are mainly driven by cross-country differences. As noted in Ravallion and Chen (1997), cross-country comparison data have many conceptual and practical problems, such as those arising from PPP currency conversions, comparisons across different survey based measures of living standards, and comparisons across countries at different levels of development.

As a result of these two limitations, there is a strong case to be made that to understand better the nature of the economic growth-poverty relationship more within country studies are needed, especially of those countries undergoing rapid change. From this perspective a detailed study of poverty outcomes in China is likely to be particularly important given the

\footnotetext{
${ }^{1}$ Whether more income growth is enough to increase the income of the poor has always attracted attention. The main results from the early literature, extending across many countries, are mixed(see, for example, Fishlow, 1972; Ahluwalia et al., 1974; Cline, 1975; and Fields, 1977). Recent studies, using 1980s and 1990s data, mainly conclude that economic growth has been pro-poor. The current debate has been focussed on the degree to which economic growth reduces poverty (Ravallion and Chen, 1997; Dollar and Kraay, 2000; Ravallion, 2001; Chen and Ravallion, 2001; Sala-i-Martin, 2002, and Bourguignon and Morrisson, 2002. See also Deaton (2003) for a detailed review.
} 
large population and the rapid changes that have been occurring in economic growth, income inequality, and economic reform.

The majority of China poverty studies are concentrated on rural poverty (Lee and Ma, 1994; Jalan and Ravallion, 1998, 2002; Brown and Park, 2002). Lately, due to the 1990s' radical urban reform, urban poverty has begun to attract more attention from both policy makers and academics (Gustafsson and Wei, 2000; Knight and Li, 2001; Khan and Riskin, 2001; Fang, Zhang, and Fan, 2002; China Urban Poverty Research Group (CUPRG), 2003). As stated in a report by the Asian Development Bank on urban poverty in China (2002) "Until the beginning of the 1990s, poverty was regarded as a largely rural phenomenon and the rural poor were the focus of the anti-poverty policies of the Chinese government. ...But in the 1990s poverty has come to be seen as a problem that potentially threatens a substantial percentage of the urban population."

Most current studies of Chinese urban poverty use survey data from a few provinces or for a short period and tend to be descriptive. Very few investigate the determinants of the change in poverty. In this study we utilise data from the National Statistical Bureau Urban Household Income and Expenditure Survey (UHIES) for the whole country (29 provinces) and for the period 1986 to 2000. These data will present a more general picture of urban poverty and inequality change over the 15 year economic reform period. ${ }^{2}$ More importantly, our data allow us to examine the association of the change in institutional settings and household behaviour on the one hand and the change in poverty on the other. With the unprecedent income growth during this period, and the significant inter-regional variation of the growth rate, our study may also contribute to the understanding of growth, poverty, and inequality issues beyond China.

The paper is structured as follows. The next section discusses the data and the measurement of poverty. Section 3 presents estimated poverty lines and poverty head count indices. Section 4 investigates the relationship among poverty, inequality and income growth. Conclusions are given in Section 5.

\footnotetext{
${ }^{2}$ Although the UHIES may have its own problems with respect to the sampling procedures, especially in recent years (Gibson, Huang, and Rozelle, 2003), it is still the most comprehensive nation wide survey available in China.
} 


\section{Data and poverty measurement}

The UHIES began in 1956 and was resumed in 1980 after its suspension during the Cultural Revolution (Fang et al. 2002). The survey samples households with Urban Household Registration for every province in the nation (29 provinces before 1990 and 30 after 1990 due to the newly established province 'Hainan' in 1990). The sample is based on several stratifications at the regional, provincial, county, city, town, and neighbourhood community levels. Households are randomly selected within each chosen neighbourhood community and are expected to keep a diary of all expenditures (disaggregated for hundreds of product categories) for each day for a full year. Enumerators visit sample households once or twice each month to review the records, assist the household with questions, and to take away the household records for data entry in the local Statistical Bureau office (Han, Wailes, and Cramer, 1995; Fang et al., 2002; and Gibson Huang, and Rozelle, 2003). The earliest electronic data available is from 1986.

The total number of households per year ranges from 12,409 to 16,905 and the total number of individuals ranges from 35,895 to 55,867 (see Appendix A). ${ }^{3}$ The UHIES only includes households with Urban Household Registration. Rural migrants to urban cities are not included in the survey. As rural migrants disproportionally constitute the lower end of the income distribution in urban China, excluding them may result in under-estimates of urban inequality and poverty incidence. This should be borne in mind when interpreting the results.

The measurement of a poverty line is a crucial issue and, although social conventions are important in defining poverty the best empirical approach to poverty measurement often depends on data availability. A commonly used measure is US\$1 (or US\$1.5) per person per day. This is a useful measure in that it appears to be representative of poverty lines found among low-income countries (Ravallion, Datt, and Van de Walle, 1991). Despite its widespread use, however, the measure is not ideal. First, its application often ignores price variations among different regions and over different time periods within a particular country. Second, this poverty measure uses the purchasing power parity exchange rate, with its well known failings as a measure of the local cost of living (Ravallion and Chen, 1997).

\footnotetext{
${ }^{3}$ Due to the small sample size, we exclude Tibet from our sample.
} 
Another way to measure poverty line is to follow Ravallion (1994) and CUPRG (2003) to calculate the poverty line using "the cost-of-basic-needs" (CBN) method. The CBN method defines the poverty line in four steps (Ravallion, 1994).

The first step defines the cost of acquiring "the minimum nutrition requirement" (MNR). The MNR used in this study is 2,100 calories per person per day, which is commonly used in many poverty studies (Ravallion, 1994; Pradhan, Suryahadi, Sumarto, and Pritchett, 2003) and accepted as the MNR by the Chinese Academy of Preventive Medicine (CAPM, 2001).

The second step chooses a reference group, which purchases the MNR at a lowest possible price. The reference group used in this study is the poorest 20 per cent of households (ranked by household expenditure excluding expenditure on durable goods) in each province for each survey year.

The third step measures the cost of acquiring the MNR by the reference group. This is defined as food poverty line. Food poverty line is calculated from the UHIES. An advantage of using the UHIES is that it collects detailed information on both quantity and expenditure of food purchased. The quantity data allow us to calculate the per capita nutrition intake for each household according to the composition of nutrients in each type of food as calculated by the Chinese Academy of Preventive Medicine (CAPM, 2001). ${ }^{4}$ Food expenditure per capita for the reference group is then divided by the per capita calorie intake for the same group to derive the average cost per calorie consumed by the reference group. This average cost is multiplied by 2,100 to produce the food poverty line.

The fourth step is to calculate the non-food component of the cost of basic needs (CBN) as human beings not only need food to survive, they also need other things such as basic clothing and shelter.

The non-food component of the $\mathrm{CBN}$ is derived based on the approach stated in Ravallion (1994). The basic idea of defining the non-food component of basic needs is to find the amount

\footnotetext{
${ }^{4}$ One important data issue is that the survey questionnaire was changed in 1988 and again in 1992. The main changes in 1988 were to include some individual characteristics, such as industry of employment and occupation, which should have no significant effect on the data used in our study. More significant changes were made in 1992. Apart from changes in questions related to household members' main income sources, the most important change related to this study is the food list included. The number of food items included in the earlier survey is 39. Since 1992 the food items included have increased to 112. Consequently, calculated nutrition intakes are more accurate in the later data.
} 
of basic food expenditure poor households, whose total expenditure is equal to the food poverty line, are willing to forego in order to obtain non-food consumption and to add this forgone food expenditure to the food poverty line to calculate the total poverty line.

To identify the non-food component of the CBN a relationship between food and total expenditure is estimated from the following equation:

$$
Y_{i}^{F} / Y_{i}^{T}=\alpha+\beta \log \left(Y_{i}^{T} / Z_{j}^{F}\right)+\gamma \log \left(N_{i}\right)+\varepsilon_{i}
$$

where $Y_{i}^{F}$ and $Y_{i}^{T}$ are the food and total expenditures of household $i$, respectively, $Z_{j}^{F}$ is the food poverty line for province $j$, and $N_{i}$ is the number of family members in household $i$, which is included to capture the impact of economies of scale. The parameters obtained from these estimations are then used to identify a lower and a upper bound poverty line.

The lower poverty line is defined as the food poverty line plus the amount of food expenditure a household with total expenditure equal to the food poverty line is willing to forgo to buy nonfood items. This is depicted in Figure 1. The vertical and horizontal axes represent food and total expenditures, respectively. The curve $Y_{F}$ is the estimated food expenditure curve, while the point $Z^{F}$ on the vertical axis indicates the food poverty line. On the basis of the food expenditure curve, those whose total expenditure equals $Z^{F}$ spend only a proportion $\left(\alpha_{0}\right.$, where $\alpha_{0}$ is equal to $\left.\alpha+\gamma \log (N)\right)$ of total expenditure on food. The remaining proportion, $\left(1-\alpha_{0}\right)$, is spent on non-food. Thus, $\left(1-\alpha_{0}\right) Z^{F}$ is the amount of total expenditure that poor households at the food poverty line are willing to forego in order to obtain necessary non-food consumption. The lower poverty line, therefore, is defined as the food poverty line $\left(Z^{F}\right)$ plus the necessary non-food component of consumption $\left(\left(1-\alpha_{0}\right) Z^{F}\right)$. From equation 1 we know that if $Y_{i}^{T}=Z_{j}^{F}$, the food share of the total expenditure is equal to $\alpha_{0}$. Thus, the lower bound of the poverty line $Z^{L}$ can be derived as:

$$
Z^{L}=Z^{F}\left(2-\alpha_{0}\right)
$$

The upper bound of the poverty line, $Z^{U}$ in Figure 1, is defined as the total expenditure at which a household spends $Z^{F}$ on food. Formally, $Z^{U}=Z_{j}^{F} /\left(Y_{i}^{F} / Y_{i}^{T}\right)^{*}$, where, $\left(Y_{i}^{F} / Y_{i}^{T}\right)^{*}$ 
is the food share of the total budget at the point where $Y_{i}^{F}=Z_{j}^{F}$. Thus, equation 1 can be re-written as:

$$
\left(Y_{j}^{F} / Y_{i}^{T}\right)^{*}=\alpha_{0}+\beta \log \left(Y_{i}^{T} / Y_{j}^{F}\right)^{*}
$$

Following Ravallion (1994) and approximating $\log \left(Y_{j}^{F} / Y_{i}^{T}\right)^{*}$ by $\left(Y_{j}^{F} / Y_{i}^{T}\right)^{*}-1$, the upper bound of the poverty line, $Z^{U}$, can be approximately written as:

$$
Z^{U}=Z^{F}\left(\alpha_{0}+\beta\right) /(1+\beta)
$$

where $\beta$ is the slope of the food consumption curve in equation 1.

Once the poverty lines are calculated we apply them to income and expenditure distributions and measure the poverty rate as a head count index - the proportion of people whose income or expenditure (excluding durable good consumption) is less than the upper or lower bound poverty lines. ${ }^{5}$

\section{Poverty lines and the poverty head count indices}

\subsection{A practical consideration: The calculation of poverty lines through time}

Many researchers using estimated parameters of equation (1) from cross section data for one year, and perhaps for each region, calculate the poverty line, and then use CPI changes to adjust the CBN through time (see, for example, Ravallion and Chen, 2004). The Chinese UHIES data are quite extensive, however, and we have sufficient data to estimate the poverty line directly for each province and each year. Would that be a better strategy?

The arguments for calculating a CBN at a point of time, and then applying CPI adjustments through time, rather than repeated estimation of a new $\mathrm{CBN}$ index for each year and region, are usually based on the idea that there is value in measuring poverty in terms of a fixed bundle of goods and based on the practical consideration that data requirements for CPI adjustment are

\footnotetext{
${ }^{5}$ The income and expenditure data are measured at the household level. We use per capita income/expenditure weighted by household size to obtain the poverty head count indices.
} 
minimal. However, there are three points that should be noted. The analytical underpinnings of this technique require that (i) the fixed bundle of goods, upon which the $\mathrm{CBN}$ is based, is always available over the data period (ii) institutional changes have not had significant implications for the way in which non-food necessities are acquired and, (iii) CPI changes, which uses the consumption bundle of the average income level to weigh the price level, parallel the changes in the CBN price index, where the weights used should be developed from the consumption bundle of the low income group. Over the 15 year data period, however, urban China has experienced so much income growth, so many institutional changes and such significant changes in relative prices that the gap between these restrictive requirements and reality may be so great that it is difficult to feel confident about the results generated by the application of the CPI adjustment method. Below we consider each of these three requirements in more detail.

First, rapid increases in urban income have meant that some low price food products that are significant for the poor, and are available at the beginning of the period, may have disappeared from the market at the end of the period. For example, whole meal flour used to be a low price food for the urban poor in the 1980s, and, by the mid 1990s, it could not be found in the market place, except for whole meal flour bread which is sold in super markets as a luxury food. Conversely, food products available for the poor at the end of the period may not have been available at the start of the period. During such rapid change it is difficult to accept that a fixed bundle of goods can maintain its relevance over 15 years.

Second, institutional reforms have lead to large changes in the provision of many non-food necessities. For example, health care, education and housing, which used to be provided by the state at highly subsidised prices, or for free, have been subject to large price increases accompanying a move to user pay principles. As a result, households over the 1990s have been required to spend more on non-food necessities. ${ }^{6}$ Figure 2 provides evidence of this for households with mean income, and households with income below the 30th percentile. Over the 15 year data period the proportion of expenditure on these three items has more than doubled for both groups. This suggests that the increase in expenditure on these items is not

\footnotetext{
${ }^{6}$ For example, according to the Chinese Academy of Social Sciences' 1988 and 2002 Income Distribution Surveys, the proportion of urban residents whose health expenditure was fully covered by the state was 66 per cent in 1988 and dropped to 20 per cent in 2002
} 
due to an income effect given the very different income growth rates for these groups. It also indicates that the switch between food and non-food components of the consumption bundle flows inevitably from the institutional changes and a fixed bundle of goods over 15 years does not suit the Chinese situation when such significant changes are occurring.

Third, reforms have led to significantly different price changes for different income groups. Perhaps the clearest example relates to grain products. More than 50 to 60 percent of the calories of the urban poor (20th percentile and below) are derived from grain products. ${ }^{7}$ Deregulation of the grain market during the early 1990s replaced ration coupons and administered prices by market prices and led to very large grain price increases, relative to the CPI. ${ }^{8}$ The price impact of the grain reforms can be seen in Figure 3 which presents a range of official price indices - the CPI, the urban food retail price index and the urban grain retail price index. ${ }^{9}$ All price indices moved in a similar fashion over the 1980s but began to diverge rapidly during the reform period of the early 1990s. Between 1986 and 1996, for example, the CPI increased approximately three fold, the urban food retail price index increased three and a half fold but the urban grain retail price index increased six fold. This evidence suggests that CPI changes are unlikely to parallel price changes of the CBN. Adjustments to poverty lines based on a CPI index are likely to overstate the growth of real income of the poor who spend a disproportionate share of their income on grain products and are particularly vulnerable to relative price increases of grain. The difficulties that arise with respect to the grain price extend to other goods. Before the reforms, there was widespread use of coupons for food and other necessities that provided these goods at subsidized prices and were initially distributed according the number of family members and age. Although after the price reform there was some income compensation through the

\footnotetext{
${ }^{7}$ Data revealed from UHIES.

${ }^{8}$ From the mid-1950s, the Chinese urban population purchased food products at a highly subsidised price through a coupon ration system, whereby the coupons were distributed according to the number of family members and their ages. In the late 1970s and early 1980s a successful market oriented economic reform in the agriculture sector led to a significant increase in agriculture production and the introduction of a two-tier food price system in urban areas from the mid-1980s. During this period, urban households still received subsidised coupons but they were also free to purchase better and more varieties of food in the market place. The two-tier price system lasted until the late 1980s and in 1991-1992, the government gradually increased subsidiesd food prices so that the two-tier prices were almost equal to each other (Tang, 1998). By 1993 most of the provinces (28 out of 31) abolished the coupon ration system (Crook, 1997; Tang, 1998; People's Daily, 2002).

${ }^{9}$ The urban CPI by detailed categories are only available from 1994 . For continuity reason, we use urban retail price index by categories, which have both food and grain price indices for the entire period of our study. The difference between urban CPI and retail price index is minimal.
} 
wage structure for removing these coupons, it is quite possible that the poor were not fully compensated because their labour market involvement per family member was lower.

Each of these three concerns lead us to calculate the CBN for each province and each year, rather than apply the CPI index to a "one-off" CBN calculation. The implications of our poverty line calculations are two-fold: First, we allow the poor in each region, and over time, to change the pattern of food consumption in response to changes in food availability and prices. Second, we allow the poor to substitute non-food necessities for food in response to reforms which significantly lifted prices of many non-food necessities such as education, healthcare and housing. Poverty lines calculated in this manner, therefore, are not based on a fixed basket of goods. ${ }^{10}$ Allowing for substitution within and between food products and non-food necessities, however, would seem to be essential during a period of such rapid and extensive institutional change.

\subsection{Poverty line}

For each year and province the food poverty line, together with the lower and upper bound poverty lines, measured in nominal prices, are calculated according to equations (2) and (4) in section 2 and are reported in Tables B1, B2, and B3 of Appendix B. ${ }^{11}$ The variation in the food poverty lines and lower and upper bound poverty lines among provinces and over time are a reflection of responses to differences in food and non-food prices and preferences. The changes of these poverty lines through time, however, are very similar across provinces.

To demonstrate the average change in the poverty line we aggregate poverty lines across provinces and present the calculation as a national average in Figure 4. The food poverty line increases steadily until 1992 and then increases rapidly between 1992 and 1997 after which it exhibits a slight decline. The upper and lower poverty lines, which include non food necessities,

\footnotetext{
${ }^{10}$ Of course it not usual for statistical agencies to maintain fixed CPI weights during periods of rapid change but at this point we have not been able to determine how official CPI weights have been determined for urban China.

${ }^{11}$ The ADB (2002) used exactly the same method and same data to calculate the poverty line for different provinces in urban China in 1998. Comparing our results for 1998 with ADB (2002), small discrepancies are observed. Our understanding is that the differences come mainly from the calculation of $\alpha_{0}$, in our calculation we use the formula: $\alpha_{0}=\widehat{a}+\widehat{\gamma} \overline{\log (N)}$ whereas in $\operatorname{ADB}(2002) \alpha_{0}$ is defined as $\widehat{a}+\widehat{\gamma} \log (\bar{N})$.
} 
follow a similar path. Figure 4 also includes the aggregate food poverty line as a proportion of the upper and lower poverty line (right hand scale). The food proportions were more or less constant until the mid 1990s and then declined slightly over the period, indicating an increase in the substitution of non-food necessities for food. In 1986 the food proportions were 66 and 76 per cent of the upper and lower poverty lines, declining to 58 and 73 per cent, respectively, in 2000 .

The aggregate poverty lines, measured in nominal prices, are also included in Figure 3 as indexes, $1986=100$, where they can be compared with official price indices. The two most interesting comparisons are with the CPI - the index usually adopted to adjust a "one-off" CBN calculation - and the urban grain price index - since the poverty lines are mainly based on 2,100 calorie consumption and the reference group spends a considerable proportion of their income on grain products.

The first point to note from Figure 3 is that over the period as a whole the CPI index increases three fold and the poverty lines increase five fold, which is approximately the same increase as the urban grain price index. Our poverty line, therefore, increases much more relative to the price levels of the bundle of goods included in the CPI, but, more or less in accord to the change in urban grain price index.

The second point to note is that the 1986-2000 time span can be divided into three periods. Between 1986 and 1991 all price indices and poverty lines increase slowly and in a similar fashion, then, during 1991-1995, a period of general inflation and rapid reform of the urban grain market, the urban grain price index increases six fold while the CPI approximately doubles. This is the period during which there is a large change in our poverty lines relative to the CPI. Finally, as the grain price index falls over the third period, 1996-2000, the rapid growth of the poverty lines cease and the effect of the falling urban grain price index on the poverty lines appear to be offset by the increased need to buy non-food necessities.

It is clear from these comparisons that the choice of adjusting a fixed CBN by the CPI or adopting our method of calculating a new CBN for each year makes a considerable difference, particularly during the 1991-1995 period. The different poverty lines produced by each method suggests that further work needs to be done to document and analyse the changing prices faced 
by the urban poor.

\subsection{Poverty head count}

Using the upper and lower bound poverty lines, we calculate poverty head-count indices in terms of income and expenditure for urban China as a whole (Figure 5 and Table 1). The poverty rate changes over time are similar for the upper and lower bound poverty lines. The levels, however, vary considerably. The discussion below will focus on two features of Figure 5 . These features are common to both the upper and lower bound poverty measures. ${ }^{12}$

First, the poverty rate is higher in the 1990s than in the 1980s, especially for expenditure measured poverty. The proportion of households below the upper and lower poverty lines has been above 10 and 5 per cent for most of the 1990s, respectively, whereas in the 1980s these ratios were around 6 and 3 per cent, respectively. The most obvious changes occurred between 1991 to 1993. After 1993 the average urban poverty rate remained high until 1997 and begun to fall slightly afterwards. ${ }^{13}$

The significant increase in poverty in the early 1990s may be a combination of many factors, including the increasing need to spend on non-food necessities and the increase in non-food and food price levels, which we discussed earlier. In addition to these factors, income inequality increased much more in 1993 than previously. This is shown in Figure 6 in the next section.

The high poverty rate persisted between 1993 and 1997. This may be also related to a relatively lower income growth period between 1994 and 1997 than the earlier period due to an increase in unemployment rate. Based on the UHIES data, household real income per capita increased by 5.2 per cent per annum over the entire period (1986-2000), but between 1994 and 1997, the annual growth rate is only 3.6 per cent.

The second interesting feature of Figure 5 is that there is a large discrepancy between income and expenditure measured poverty rates. A common finding in the inequality-poverty

\footnotetext{
${ }^{12}$ The change in the poverty head-count indices (upper bound measure) by provinces are presented in Appendix $\mathrm{C}$ and the two features discussed below are present in almost every province. There is considerable variations across provinces with regard to the timing of the changes in poverty rate which is related to the variation in the timing of the various reforms.

${ }^{13}$ Note that the change in the questionnaire is occurred in the 1992 survey, whereas the most significant increase in the expenditure measured poverty rate is observed in 1993. Hence, it is unlikely that this observation is due to the inconsistency in the data collection.
} 
literature in most countries is that the income distribution is more unequal than the expenditure distribution and that in any cross section, poor households normally spend more than they earn (Cutler and Katz, 1992 and Barrett, Crossley, and Worswick, 2000). Thus, the poverty headcount measured in terms of income is usually higher than that measured in terms of expenditure. We find the opposite.

There may be two contributing factors to this result. One possibility is that in most surveys there is a serious under-reporting of income in poor households. Perhaps this is not true of the UHIES due to the institutional setting in which the data are collected. Expenditure and income are collected from a year-long diary and the statistical agency visits each household each month to check the income and expenditure records. ${ }^{14}$

Another contributing factor relates to a more interesting economic phenomenon, namely saving patterns among households with relatively low income. In the 1990s most households in urban China have been saving more, perhaps as a response to the increase in anticipated future expenditure and income uncertainty. Before economic reform started in the late 1970s urban households enjoyed lifetime employment and a cradle-to-grave social security system. These features of the planned economy did not change significantly in the 1980s reform period. The radical reform measures implemented in the 1990s changed this situation. By the mid 1990s a large number of urban state sector employees were being laid off. In addition, housing subsidies were reduced to a very low level and the majority of households began preparing to buy their own housing rather than renting from the state. Health cover was changed from 66 per cent coverage by the state in 1988 to a coverage rate as low as 22 per cent in 2002 (see footnot 6 on page 7). School tuition fees (primary, secondary, and tertiary fees) were increased significantly. Furthermore, the state provided pension system was changed to an individual account system, which inevitably meant decreased pension coverage for larger segment of the population (see Meng (2003) for a detailed discussion of these changes). With all these changes occurring at once, urban households began to realise that their future welfare would depend heavily on their own savings given the lack of development of credit markets, especially for the

\footnotetext{
${ }^{14}$ It may also reflect the fact that Chinese households rarely borrowed before the late 1990s when the housing market became well developed.
} 
poor. The sudden change in welfare provision signaled a sudden drop in permanent income and a significant increase in future income uncertainty. When this happened, the need to save more was so great that a large group of households suppressed their current consumption to such a degree that many fell below the poverty line even though their income was sufficient to place them above the poverty line.

How do our poverty head count indices compare with other studies? In general, the poverty head-count indices presented in this study are higher than many previous studies, which typically report poverty levels of around one per cent for urban China (World Bank, 1992, 1997, 2000; Yao, 2000; Chen and Wang, 2001). ${ }^{15}$

Khan and Riskin (2001), however, using the Chinese Academy of Social Sciences' 1988 and 1995 Urban Household Survey data came up with higher urban poverty figures. ${ }^{16}$ Moreover, Fang et al (2002) using US\$1 per day and six years UHIES data (1992 and 1994-1998) for a sample of 3600 households each year (one city per province) found poverty incidences of 2.09, $2.73,1.65,1.69,2.00$, and 2.06 per cent for the six years, respectively. These are almost the same as our income measured poverty rates based on lower poverty line. Using US $\$ 1.5$ per day they find a significant jump in poverty rates to levels similar to our poverty rates measured in expenditure and based on the upper poverty line.

The definition of poverty in many studies is largely arbitrary and it is to be expected that poverty levels will vary across studies. What is more important, however, is the changing levels of poverty through time and it is in this dimension that the extensive data based analysis in this study enables us to make a special contribution. These data, combined with CBN calculations

\footnotetext{
${ }^{15}$ For example, the World Bank (1992) using 2150 calorie per person per day (cal/day) as a minimal energy intake reports an urban poverty incidence of far less than 1 per cent up to 1990. Chen and Wang (2001) using US\$1 per person per day calculated lower than 1 per cent poverty rate for the whole 1990s. Yao (2000), using data for two provinces and a fixed 454 yuan in 1990 prices as the poverty line, suggests that over 1986 to 1993 period the poverty head count index in the two provinces never exceeded 1 per cent.

${ }^{16}$ Based on household income and using 2100 calorie per person per day plus a non-food component, their poverty head count indices are 8.8 and 8.0 per cent for 1988 and 1995, respectively. This is much higher than our estimates based on household income and the upper bound poverty line, which is 3.1 and 5.1 per cent, respectively, for 1988 and 1995. In addition, their poverty measure does not reflect the significant increase in poverty rate in the early 1990s. This may be due to the fact that their poverty line measure is calculated using aggregated data, which makes it hard to take into account the price differences at different income levels, for different regions, and different commodities. Interestingly, using a poverty line equal to 80 per cent of the value of their estimated poverty line, their calculation of the poverty rate is 2.7 and 4.1 per cent for the two years, respectively, a very close measure to what we observed in our study both in terms of level and trend.
} 
for each province and each year, reveals a distinctive pattern of poverty changes through time, a dimension of poverty analysis that to this point has been severely prescribed by lack of data.

\section{Relationship among poverty, inequality, and income}

To place the changing level of urban poverty in a broad context, Figure 6 presents the average real per capita income and expenditure, as well as inequality of income and expenditure between 1986 and 2000. The income and expenditure are deflated using provincial level urban consumer price index. The inequality measures are average provincial Gini coefficients, which are consistent with poverty measures presented earlier. ${ }^{17}$

A number of noticeable features are evident in Figure 6. First, over the 1986-2000 period, per capita real income and expenditure (left hand scale) increased quite rapidly in urban China, especially since 1989. The strongest growth periods were 1989-1994, and 1998-2000. Over the period as a whole per capita real income increased at an average annual rate of 5.2 per cent.

Second, the positive income-expenditure gap, evident in the poverty rates, is also evident on a per capita basis for all households. Furthermore, the marked difference between income and expenditure has increased over time. In 1986 urban per capita household income exceeded per capita expenditure by 12 per cent and this ratio increased to 20 per cent in 2000 . The increase in the saving rate mainly occurred in the 1990s.

Third, inequality whether calculated in terms of per capita income or expenditure has increased. The per capita income Gini coefficient (right hand scale) increased from 0.20 in 1986 to 0.32 in 2000 . The per capita expenditure Gini coefficient changed in a similar fashion. The largest increases occured in the early 1990s. Many studies have found that one of the main contributing factors to the fast increase in inequality in the early 1990s is the increase in inequality across regions rather than within each region (Knight and Li, 1999; Khan and Riskin, 2000; Riskin, Zhao, and Li, 2001).

How are these changes in income and inequality associated with changes in our poverty measures? The causal relationships are not straightforward and under special circumstances there is an identity relating changes in poverty head counts to changes in the poverty line,

\footnotetext{
${ }^{17}$ The income, expenditure, and inequality measures for each province are presented in Appendix D.
} 
mean income and income distribution (Datt and Ravallion, 1992 and Bourguignon, 2003). For example, given the poverty line and income distribution an increase in mean income reduces poverty. Likewise, given mean income and the poverty line an increase in inequality, which preserves the pre existing symmetry of the income distribution, increases poverty. Finally, increasing the poverty line, keeping income distribution and mean income constant increases the poverty head count. In this study we do not seek to examine the causal relationship between poverty, inequality, and income growth, rather, we investigate the association among these variables.

To explore and summarize the links between different factors we regress the poverty head count indices against income, the inequality measure, the changing need for savings to meet the general withdrawal of welfare services, and other factors that may affect poverty such as the impact of relative food price and unemployment generated from labour market reform. The following equation is fitted to combined cross section (at provincial level) and time series data:

$$
\log \left(P_{i t}\right)=\alpha+\beta \log \left(Y_{i t}\right)+\delta \log \left(G_{i t}\right)+\eta \log \left(S_{i t}\right)+\theta \log \left(W E_{i t}\right)+\gamma \log \left(X_{i t}\right)+\mu_{i}+\varepsilon_{i t}
$$

where $P$ represents the poverty head-count index measure in terms of income or expenditure, $Y$ is the mean income, $G$ is the Gini coefficient measured in terms of income, $S$ is the average saving rate, and $W E$ is the average budget share of education, medical and housing expenditure, which is used to measure the change in the non-food component of the poverty line. $X$ is a vector of other control variables, including a time trend, the average proportion of household members unemployed, and the relative food price index for different provinces and over time. $\mu$ is a time invariant provincial dummy variables to capture unobservables, while $\varepsilon$ is a random error term. The subscripts $i$ and $t$ index provinces and time. ${ }^{18}$

Equation (5) is estimated using a fixed effects model which controls for the unobservable time invariant provincial effects and allows for the income and other effects on the change of poverty within each province over time. The unemployment variable is only available for surveys after 1987 and regressions including unemployment cover the period 1988 to 2000. In addition,

\footnotetext{
${ }^{18}$ Note that equation 5 is used to explore the association of all explanatory variables with the dependent variable. Understanding of the causal effects is beyond the scope of this study.
} 
as the Gini coefficient is strongly correlated to unemployment, we also estimate a naive version of equations (5), which excludes the Gini coefficient as a right-handside variable.

The estimated results from equation (5) are reported in Table 2. There are 3 panels in the table and 4 columns in each panel. The left panel presents estimations with neither unemployment nor Gini coefficient variables. The middle panel includes unemployment but excludes Gini coefficients, while the right panel includes Gini coefficient and excludes unemployment. Within each panel, the first two columns use the log poverty rate measured with respect to income as the dependent variable, while the third and fourth columns use the log poverty rate measured with respect to expenditure as the dependent variable. For each specification, we also estimate equation (5) with and without the saving rate.

Reading across the columns of the left panel, we find that log income is negatively and significantly associated with the log poverty rate in all cases. Within each province, higher levels of income are associated with lower levels of poverty. The most interesting result regarding the income elasticity is that income increases produce greater poverty reductions measured in terms of income than poverty reductions measured in terms of expenditure, if the saving rate is not controlled for. For example, comparing columns (1) and (3), we find that a ten per cent increase in income reduces income measured poverty by 26.1 per cent (column 1 in the left panel), whereas the same increase in income only reduces the poverty rate by 19.0 per cent (column 3 in the left panel) when it is measured in terms of expenditure.

The weaker income effect on the expenditure poverty rate confirms our finding in Section 3 that although income increased for the poor over time, not all of this increase is spent on everyday living. Indeed, when we control for the saving rate, the effect of a ten per cent income increase on the expenditure measured poverty reduction increases to 27.9 per cent (column 4 in the left panel). The saving rate is positively and significantly related to the increase in poverty measured in terms of expenditure. Every ten per cent increase in the saving rate increases the expenditure poverty rate by 11.9 per cent. This offsets 43 per cent of the effect of income increase on poverty reduction. These results suggest that to cope with an increase in income uncertainty and future expenditure need in the 1990s, poor households put more money aside. This finding is perhaps related to credit constraints for the poor households and 
the Chinese dislike of borrowing. Meng (2003) also found that the saving rate for households with unemployed members are on average positive and that the radical reform in the 1990s has induced a significant increase in precautionary saving in urban China.

In addition to the growth elasticity and the saving rate, an increase in the relative food price and an increase in the proportion of expenditure on education, medical care, and housing are significantly associated to an increases in the poverty rate. The magnitudes of these effects are large, especially for the relative food price. Every 10 per cent increase in the relative food price index increase income and expenditure measured poverty by around 33 to 40 per cent, while a 10 per cent increase in the proportion of education, medical and housing expenditure increases the two poverty rates by around 10 to 14 per cent (left panel). These effects capture the change in the poverty line arising from the change in food and non-food prices and they both seem to offset the income growth effect.

Comparing the results from the full sample (left panel) with the results from the sample which excludes the 1986 and 1987 data (middle panel), one of the most important difference is the considerably higher growth elasticity of poverty reduction using the sample excluding the earlier data points. For example, in the income-poverty equation, the elasticity increased from 2.6 to 3.4 (columns 1 and 5) and in the expenditure-poverty equation the change is from 1.90 to 2.36 (columns 3 and 7). ${ }^{19}$ The variable "average proportion of unemployed members in a household" for the restricted sample has a positive and statistically significant effect on poverty rate measured in income, with an elasticity of 0.31 , indicating that increase in unemployment contributed to an increase in poverty rate. However, this relationship does not exist with regard to the poverty rate measured in terms of expenditure. This suggests that having more unemployed members in the household reduces income at the bottom but does not reduce expenditure at the bottom. This is a reasonable result. With an additional family member becoming unemployed one should not expect a reduction in the average basic consumption for the poor household but should expect a significant reduction in average income level. This is because at the bottom, consumption is already at a subsistence level and could not be lowed

\footnotetext{
${ }^{19}$ The change in growth elasticity is not affected by the additional explanatory variable. Without including the "unemployment rate" variable, the elasticities are very similar.
} 
further.

The right hand panel of Table 2 reports the results from the estimation of the full version of equation 5. As there is a high correlation between the unemployment rate and the Gini coefficient, the coefficient for unemployment changes sign and becomes insignificant when both variables are included. We, therefore, exclude the unemployment rate from the regression. Including the log Gini coefficient increases the growth elasticity of poverty reduction. However, the effect of the $\log$ Gini coefficient is always positive and statistically significant at 1 per cent level. A 10 per cent increase in inequality is associated to a 28.4 per cent increase in poverty measured in terms of income (column 9) while the 10 per cent increase in income reduces poverty by 31.3 per cent. This suggests that for a same proportionate change the effect of the increase in income inequality on poverty offsets almost 90 per cent of the effect of income increase on poverty reduction. Intuitively, if there is a ten per cent increase in income and 10 per cent increase in inequality, the net effect will be a 3 percentage point reduction in poverty. With regard to the poverty measured in terms of expenditure (column 11), the effect is not as dramatic.

The income growth elasticities of poverty obtained in this study are quite large, indicating a very strong effect of income growth on poverty reduction. These results are comparable to, if not stronger than, other studies using cross-country data estimation (see, for example, Ravallion and Chen, 1997; Dollar and Kraay, 2001; Bournuignon, 2003). However, the effects of inequality, relative food price, proportion of expenditure spent on education, medical care, and housing, and saving all contribute positively to the increase in the poverty rate, offsetting the income growth effect.

To quantify the contributions of the change in each of the explanatory variables on the change in poverty over the 15 years period, we conduct the following decomposition exercise. Using coefficients estimated from equation (5) we predict the log poverty rate for each year and focus on the changes from 1986 to 1990, 1990 to 1993, 1993 to 1997, and 1997 to 2000. The difference in the predicted log poverty rates between the beginning and end of each of these periods are then decomposed using the change in the mean values of each variable and the estimated coefficients for the whole period presented in Table 3. Thus, the decomposition may 
be written as :

$$
\Delta \overline{\log (P)}=\widehat{\beta} \Delta \overline{\log (Y)}+\widehat{\delta} \Delta \overline{\log (G)}+\widehat{\eta} \Delta \overline{\log (S)}+\widehat{\theta} \Delta \overline{\log (W E)}+\widehat{\gamma} \Delta \overline{\log (X)}
$$

where $\Delta$ indicates the difference between the beginning and end of each such period, the hats on the coefficients indicate that they are estimates, while the bars on the variables indicate the mean values.

The decomposition results are reported in Table 3. Figure 7 plot the contribution of the change in each factor to the total change in log poverty rate measured in terms of expenditure, and provides a useful summary of the changing urban poverty history. ${ }^{20}$

First, the large increases in poverty occur in the pre 1993 periods and since then there is a marginal increase in poverty between 1993 and 1997 and then a significant drop.

Second, income growth in all periods contributes to poverty reduction. The effect is very much larger in the 1990s than in the 1980s and the most significant effect occurred in the 1990 to 1993 period. This, however, is the period of large and significant price reforms and its effect, combined with other effects, more than offset the effect of income changes on poverty.

Third, although the contribution of the Gini coefficients changes are much the same and increase poverty in all periods these increases are not a major contributor to poverty increases or to the changing path of poverty through time.

Fourth, the most important contributor to the increasing level of poverty is the impact of the food price increases relative to the CPI. It contributed positively to the increase in poverty in the first three periods and negatively in the last period.

Fifth, the increase in the budgetary share of medical, housing and education expenditures contributes to poverty increases through-out the period and, for the last period, is the major factor offsetting income growth.

Sixth, the increase in the saving rate does not appear to be important until the 1997-2000 period.

\footnotetext{
${ }^{20}$ The decomposition results of log income poverty almost mimic the results obtained from the decomposition of $\log$ expenditure poverty. The main difference, as expected, is that saving plays no role in the increase in log income poverty.
} 


\section{Conclusions and policy implication}

After 20 or so years of spectacular income growth, average living standards in urban China have improved significantly. This growth, however, has been accompanied by many other changes, including an increase in income inequality, reduced social welfare provision, an increase in urban grain prices, and increased income uncertainty. In this paper we utilised 15 years of urban household survey data to investigate how poverty has changed as a result of the income growth and other changes. The following are our main contributions and findings.

First, we used the cost-of-basic-needs $(\mathrm{CBN})$ method to calculate poverty lines for each province over the 15 years. This is the first consistent measure of urban poverty over such a long period and across all provinces. The application of this technique to the extensive household surveys (UIHES) leads to new insights into the analysis of urban poverty over this period. The most important insight is that the CBN method indicates that urban poverty has increased in the early and mid 1990s, reaching a peak in 1993, and then stabilised at a high level, finally declined after 1997. This pattern is largely generated by the differential price impact of economic reforms upon the poor who were particularly disadvantage by large increases in grain prices, relative to the CPI. The CBN method also allows us to quantify adverse impacts of economic reforms on the supply of non-food necessities, which moved from low price or free access to a market system, where price increased significantly.

Second, income growth has had a strong positive effect on poverty reduction over the 15 year period studied. We found that every ten per cent increase in income reduced poverty by between 19 to 39 per cent depending on the model specification. However, the effect of saving, the relative price of food, the need to spend more on medical, education and housing, and growing income inequality all contributed to an increase in poverty. Over the period as a whole these effects offset the positive income growth effect on poverty reduction.

Third, we observed a significant difference in poverty head-count indices measured in terms

of income and expenditure and the difference between the two measures of poverty widened significantly in the 1990s, mainly due to the increase in income uncertainty and expected future expenditure on items such as housing and education. These factors led poor households to 
save more of their limited income for future consumption even though this saving reduced expenditure to below the poverty line. This increase in saving may also reflect lack of credit access for the urban poor. This finding raises an important issue that has not received much attention in poverty studies. On the one hand, if we are interested in current living standards, expenditure measured poverty is what we should focus on. Perhaps we should be concerned that a large proportion of individuals are choosing to live under poverty. On the other hand, if we are considering future living standards, it seems quite reassuring that individuals are trying to make provisions for future needs. Households are saving for their children's education, for old age security, and for unexpected medical bills. However, the saving behaviour observed for the poor household indicates that lack of credit market for the poor is one of the main reason for the poor to give up current consumption even though that implies that they will have to live below the poverty line. In this regard, speed up the banking reform, and providing education financial supports for children from poor family may be urgently required in China.

Finally, an important caveat, which should be born in mind when interpreting our results, is that the study only includes households with urban household registration. Rural migrants, who comprise a large proportion of the urban poor, are not included. This suggests that urban poverty head count indices presented in this study understate total urban poverty. 


\section{References}

[1] Asian Development Bank, 2002, Research on Poverty in Urban China, Unpublished Report.

[2] Ahluwalia, M.S., Duloy, J.H., Pyatt. G., et al., 1980, Economic Growth and Social Equity in Developing Countries, Stanford, CA., Stanford University Press.

[3] Barrett, G., Crossley, T., and Worswick, C., 2000, "Consumption and income inequality in Australia", Economic Record, 76(233), pp.116-138.

[4] Bourguignon, F., and Morrison, C., 2002, "Inequality among world citizens: 1820-1992", American Economic Review, 92(4), pp.727-744.

[5] Bourguignon, F., 2003, "The growth elasticity of poverty reduction: explaining heterogeneity across countries and time periods", in T. Eichler and S. Turnovsky (eds) Growth and Inequality, MIT Press.

[6] Brown, P. and Park, A., 2002, "Education and poverty in rural China" , Economics of Education Review, 21(6), pp. 523-541.

[7] The Chinese Academy of Preventive Medicine, 2001, Recommended Nutrition Intake for Chinese Households, (in Chinese), Beijing: Publishing House of the Chinese Light Industry.

[8] Chen, S. and Ravallion, M., 2001, "How did the world's poorest fare in the 1990s?", Review of Income and Wealth, 47(3), pp.283-300.

[9] Chen, S. and Wang, Y., 2001, "China's growth and poverty reduction: recent trends between 1990 and 1999", Unpublished manuscript.

[10] China Urban Poverty Research Group, 2003, Urban Poverty: New Challenge for China's Development, Beijing: Chinese Economics Press.

[11] Cline, W.R., 1975, "Distribution and development:a survey of the literature", Journal of Development Economics, 1(4), pp.359-400.

[12] Crook, F., 1997, "China: is current Ag policy a retreat from reform?" Agricultural Outlook, Economic Research Service, USDA, March, 1997.

[13] Cutler, D. and Katz, L., 1992, "Rising inequality?", American Economic Review, 82(2), pp.546-551. 
[14] Datt, G., and Ravallion, M., 1992, "Growth and redistribution components of changes in poverty measures", Journal of Development Economics, 38, pp.275-295.

[15] Deaton, A., 2003, "Measuring pverty in a growing world (or measuring growth in a poor world)", NBRR Working Paper Series No. 9822.

[16] Dollar, D., and Kraay, A., 2001, "Growth is good for the poor", World Bank Working Paper.

[17] Fang, C., Zhang, X., and Fan, S., 2002, "Emergence of urban poverty and inequality in China: evidence from household survey", China economic Review, 13, pp.430-443.

[18] Fields, G., 1977, "Who benefits from economic development? A reexamination of Brazilian growth in the 1960s", American Economic Review, 67(4), pp.570-582.

[19] Fishlow, A., 1972, "Brazilian size distribution of income", American Economic Review, 62(1/2), pp. 391-402.

[20] Gibson, J., Huang, J., and Rozelle, S., 2003, "Improving estimates of inequality and poverty from urban China's household income and expenditure survey", Review of Income and Wealth, 49(1), pp.53-68.

[21] Gustafsson, B. and Wei, Z., 2000, "How and why has poverty in China changed? a study based on microdata for 1988 and 1995", China Quarterly, 164, pp.983-1006.

[22] Han, T., Wailes, E.J., and Cramer, G.L., 1995, "Rural and urban data collection in the People's Republic of China", in the China Market Data and Information Systems, Proceedings of WCC-101 Symposium, Washington, D.C.

[23] Jalan, J. and Ravallion, M., 1998, "Transient poverty in postreform rural China", Journal of Comparative Economics, 26(2), pp. 338-357.

[24] Jalan, J. and Ravallion, M., 2002, "Geographic poverty traps? A micro model of consumption growth in rural China", Journal of Applied Econometrics, 17(4), pp.329-346.

[25] Khan, A. R., and Riskin, C., 2001, Inequality and Poverty in China in the Age of Globalization, Oxford and New York: Oxford University Press.

[26] Knight, J. and Li, S., 1999, "Fiscal Decentralization, Redistribution and Reform in China", Oxford Development Studies, 27(1), pp.5-32.

[27] Knight, J. and Li, S., 2001, "Three poverties in urban China", Unpublished Manuscript. 
[28] Lee, T., and Ma, J., 1994, "Agricultural productivity and rural poverty in China", China Economic Review, 5(1), pp.141-159.

[29] Meng, X., 2003, "Unemployment, consumption smoothing, and precautionary saving in urban China", Journal of Comparative Economics, 31(3), pp.465-485.

[30] National Statistical Bureau, 1994, 1995-2001, Chinese Statistical Yearbook, Beijing: Chinese Statistical Press.

[31] People's Daily, 2002, "China finding earliest grain ration coupon”, People's Daily, 4th July, 2002.

[32] Pradhan, M., Suryahadi, A., Sumarto, S., and Pritchett, L., 2003, "Measurements of Poverty in Indonesia: 1996, 1999, and beyond", Unpublished manuscript.

[33] Ravallion, M., 1994, Poverty Comparisons, Harwood Academic Publishers.

[34] Ravallion, M., 2001, "Growth, inequality, and poverty: looking beyand the averages", World Development, 29(11), pp.1803-1815.

[35] Ravallion, M. and Chen, S., 1997, "What can new survey data tell us about recent changes in distribution and poverty?" World Bank Economic Review, 11(2), pp. 357-82.

[36] Ravallion, M., and Chen, S., 2004, "China's (uneven) progress against poverty", Paper presented at the Poverty, Inequality, Labour Market and Welfare Reform in China Conference, Canberra, August 2004.

[37] Ravallion, M., Datt, G., and van de Walle, D., 1991, "Quantifying absolute poverty in the developing world "Review of Income and Wealth, 37(4), pp. 345-361.

[38] Sala-i-Martin, X., 2002, "The disturbing 'rise' of global income inequality", NBER Working Paper Series, No.. 8904.

[39] Tang, Y., 1998, Choices: the Chinese Reform since 1978, Beijing: Economics Daily Publishing House.

[40] World Bank, 1992, China: Strategies for Reducing Poverty in the 1990s, Washington, DC: World Bank.

[41] World Bank, 1997, Sharing Rising Incomes: Disparities in China, Washington, DC: World Bank.

[42] World Bank, 2000, China: Overcoming Rural Poverty, Washington, DC: World Bank. 
[43] Yao, S., 2000 "Economic development and poverty reduction in China over 20 years of reforms", Economic Development and Cultural Change, 48(3), pp.447-474. 
Table 1 National urban poverty rate: $1988-2000$

\begin{tabular}{|c|c|c|c|c|}
\hline & $\begin{array}{l}\text { Expenditure } \\
\text { measured } \\
\text { poverty rate } \\
\text { based on upper } \\
\text { line }\end{array}$ & $\begin{array}{l}\text { Expenditure } \\
\text { measured } \\
\text { poverty rate } \\
\text { based on lower } \\
\text { line }\end{array}$ & $\begin{array}{l}\text { Income } \\
\text { measured } \\
\text { poverty rate } \\
\text { based on upper } \\
\text { line }\end{array}$ & $\begin{array}{l}\text { Income } \\
\text { measured } \\
\text { poverty rate } \\
\text { based on lower } \\
\text { line }\end{array}$ \\
\hline 1986 & 5.34 & 2.40 & 2.09 & 1.10 \\
\hline 1987 & 5.78 & 2.85 & 2.21 & 1.03 \\
\hline 1988 & 6.10 & 2.92 & 2.63 & 1.50 \\
\hline 1989 & 7.09 & 3.32 & 2.62 & 1.59 \\
\hline 1990 & 6.50 & 3.05 & 1.91 & 0.97 \\
\hline 1991 & 6.83 & 3.41 & 2.49 & 1.29 \\
\hline 1992 & 10.12 & 5.12 & 3.62 & 1.72 \\
\hline 1993 & 14.91 & 7.50 & 5.33 & 2.30 \\
\hline 1994 & 12.88 & 6.94 & 5.11 & 2.63 \\
\hline 1995 & 13.10 & 6.71 & 5.35 & 2.57 \\
\hline 1996 & 12.88 & 6.20 & 4.94 & 2.28 \\
\hline 1997 & 13.55 & 6.03 & 5.28 & 2.48 \\
\hline 1998 & 13.06 & 5.50 & 4.83 & 1.85 \\
\hline 1999 & 12.11 & 5.04 & 4.21 & 1.70 \\
\hline 2000 & 10.19 & 3.92 & 3.97 & 1.71 \\
\hline
\end{tabular}


Table 2 Estimated results from equation 5

\begin{tabular}{|c|c|c|c|c|c|c|c|c|c|c|c|c|}
\hline & \multicolumn{4}{|c|}{$\begin{array}{l}\text { Left Panel: } \\
\text { Specification } 1 \text { (without Gini and unemp) }\end{array}$} & \multicolumn{4}{|c|}{$\begin{array}{l}\text { Middle Panel: } \\
\text { Specification } 2 \text { (with unemployment) }\end{array}$} & \multicolumn{4}{|c|}{$\begin{array}{l}\text { Right Panel: } \\
\text { Specification } 3 \text { (with Gini) }\end{array}$} \\
\hline & \multicolumn{2}{|c|}{$\begin{array}{l}\text { Log(poverty) } \\
\text { (income) }\end{array}$} & \multicolumn{2}{|c|}{$\begin{array}{l}\text { Log(poverty) } \\
\text { (expenditure) }\end{array}$} & \multicolumn{2}{|c|}{$\begin{array}{l}\text { Log(poverty) } \\
\text { (income) }\end{array}$} & \multicolumn{2}{|c|}{$\begin{array}{l}\text { Log(poverty) } \\
\text { (expenditure) }\end{array}$} & \multicolumn{2}{|c|}{$\begin{array}{l}\text { Log(poverty) } \\
\text { (income) }\end{array}$} & \multicolumn{2}{|c|}{$\begin{array}{l}\text { Log(poverty) } \\
\text { (expenditure) }\end{array}$} \\
\hline & (1) & (2) & (3) & (4) & (5) & (6) & (7) & $(8)$ & (9) & $(10)$ & (11) & $(12)$ \\
\hline Constant & $\begin{array}{l}41.091^{* * *} \\
(3.198)\end{array}$ & $\begin{array}{l}44.105^{* * *} \\
(3.832)\end{array}$ & $\begin{array}{l}33.590^{* * *} \\
(2.637)\end{array}$ & $\begin{array}{l}42.337^{* * *} \\
(3.067)\end{array}$ & $\begin{array}{l}48.502^{* * *} \\
(3.378)\end{array}$ & $\begin{array}{l}52.860^{* * *} \\
(3.892)\end{array}$ & $\begin{array}{l}36.510^{* * *} \\
(2.980)\end{array}$ & $\begin{array}{l}44.850^{* * *} \\
(3.363)\end{array}$ & $\begin{array}{l}48.668^{* * *} \\
(3.044)\end{array}$ & $\begin{array}{l}50.631^{* * *} \\
(3.582)\end{array}$ & $\begin{array}{l}37.483^{* * *} \\
(2.677)\end{array}$ & $\begin{array}{l}45.419^{* * *} \\
(3.053)\end{array}$ \\
\hline Log(real income) & $\begin{array}{l}-2.612^{* * *} \\
(0.312)\end{array}$ & $\begin{array}{l}-2.918^{* * *} \\
(0.379)\end{array}$ & $\begin{array}{l}-1.901^{* * *} \\
(0.260)\end{array}$ & $\begin{array}{l}-2.794^{* * *} \\
(0.306)\end{array}$ & $\begin{array}{l}-3.431^{* * *} \\
(0.370)\end{array}$ & $\begin{array}{l}-3.853^{* * *} \\
(0.415)\end{array}$ & $\begin{array}{l}-2.359^{* * *} \\
(0.333)\end{array}$ & $\begin{array}{l}-3.171^{* * *} \\
(0.363)\end{array}$ & $\begin{array}{l}-3.130^{* * *} \\
(0.291)\end{array}$ & $\begin{array}{l}-3.332^{* * *} \\
(0.350)\end{array}$ & $\begin{array}{l}-2.170^{* * *} \\
(0.258)\end{array}$ & $\begin{array}{l}-2.989^{* * *} \\
(0.301)\end{array}$ \\
\hline Log(Gini) & & & & & & & & & $\begin{array}{l}2.838^{* * *} \\
(0.321)\end{array}$ & $\begin{array}{l}2.818^{* * *} \\
(0.322)\end{array}$ & $\begin{array}{l}1.437^{* * *} \\
(0.288)\end{array}$ & $\begin{array}{l}1.340^{* * *} \\
(0.280)\end{array}$ \\
\hline Log(saving rate) & & $\begin{array}{l}0.402 \\
(0.282)\end{array}$ & & $\begin{array}{l}1.192^{* * *} \\
(0.231)\end{array}$ & & $\begin{array}{l}0.663^{* *} \\
(0.299)\end{array}$ & & $\begin{array}{l}1.281^{* * *} \\
(0.265)\end{array}$ & & $\begin{array}{l}0.269 \\
(0.259)\end{array}$ & & $\begin{array}{l}1.117^{* * *} \\
(0.225)\end{array}$ \\
\hline Log(rate of unemp.) & & & & & $\begin{array}{l}0.312^{* * *} \\
(0.070)\end{array}$ & $\begin{array}{l}0.311^{* * *} \\
(0.070)\end{array}$ & $\begin{array}{l}0.072 \\
(0.063)\end{array}$ & $\begin{array}{l}0.070 \\
(0.061)\end{array}$ & & & & \\
\hline Log(food price index) & $\begin{array}{l}3.893^{* * *} \\
(0.311)\end{array}$ & $\begin{array}{l}3.965^{* * *} \\
(0.314)\end{array}$ & $\begin{array}{l}3.364^{* * *} \\
(0.259)\end{array}$ & $\begin{array}{l}3.551^{* * *} \\
(0.253)\end{array}$ & $\begin{array}{l}4.209^{* * *} \\
(0.299)\end{array}$ & $\begin{array}{l}4.333^{* * *} \\
(0.302)\end{array}$ & $\begin{array}{l}3.326^{* * *} \\
(0.267)\end{array}$ & $\begin{array}{l}3.559^{* * *} \\
(0.263)\end{array}$ & $\begin{array}{l}3.921^{* * *} \\
(0.284)\end{array}$ & $\begin{array}{l}3.969^{* * *} \\
(0.287)\end{array}$ & $\begin{array}{l}3.371^{* * *} \\
(0.251)\end{array}$ & $\begin{array}{l}3.546^{* * *} \\
(0.246)\end{array}$ \\
\hline $\log (\text { rmeh })^{(1)}$ & $\begin{array}{l}1.447^{* * *} \\
(0.350)\end{array}$ & $\begin{array}{l}1.437^{* * *} \\
(0.349)\end{array}$ & $\begin{array}{l}0.969^{* * *} \\
(0.288)\end{array}$ & $\begin{array}{l}0.955^{* * *} \\
(0.279)\end{array}$ & $\begin{array}{l}1.113^{* * *} \\
(0.391)\end{array}$ & $\begin{array}{l}1.064^{* * *} \\
(0.389)\end{array}$ & $\begin{array}{l}0.881^{* *} \\
(0.349)\end{array}$ & $\begin{array}{l}0.776^{* *} \\
(0.339)\end{array}$ & $\begin{array}{l}1.117^{* * *} \\
(0.321)\end{array}$ & $\begin{array}{l}1.113^{* * *} \\
(0.321)\end{array}$ & $\begin{array}{l}0.819^{* * *} \\
(0.281)\end{array}$ & $\begin{array}{l}0.816^{* * *} \\
(0.273)\end{array}$ \\
\hline Time trend & $\begin{array}{l}-0.013 \\
(0.032)\end{array}$ & $\begin{array}{l}-0.002 \\
(0.033)\end{array}$ & $\begin{array}{l}-0.005 \\
(0.026)\end{array}$ & $\begin{array}{l}0.025 \\
(0.026)\end{array}$ & $\begin{array}{l}0.037 \\
(0.040)\end{array}$ & $\begin{array}{l}0.052 \\
(0.041)\end{array}$ & $\begin{array}{l}0.026 \\
(0.036)\end{array}$ & $\begin{array}{l}0.056 \\
(0.036)\end{array}$ & $\begin{array}{l}-0.032 \\
(0.029)\end{array}$ & $\begin{array}{l}-0.024 \\
(0.030)\end{array}$ & $\begin{array}{l}-0.016 \\
(0.026)\end{array}$ & $\begin{array}{l}0.013 \\
(0.026)\end{array}$ \\
\hline No. of obs. & 420 & 420 & 427 & 427 & 367 & 367 & 369 & 369 & 420 & 420 & 427 & 427 \\
\hline No. of obs. & 29 & 29 & 29 & 29 & 29 & 29 & 29 & 29 & 29 & 29 & 29 & 29 \\
\hline R-Squared: Within & 0.41 & 0.41 & 0.42 & 0.46 & 0.47 & 0.47 & 0.40 & 0.44 & 0.51 & 0.51 & 0.46 & 0.49 \\
\hline R-Squared: Overall & 0.35 & 0.35 & 0.28 & 0.30 & 0.36 & 0.36 & 0.24 & 0.26 & 0.45 & 0.45 & 0.29 & 0.30 \\
\hline
\end{tabular}

Note: (1) rmeh is the budget share of medical, education, and housing expenditure. 
Table 3 Decomposition of poverty rate changes for selected periods

\begin{tabular}{|c|c|c|c|c|}
\hline Expenditure & $1986-1990$ & $1990-1993$ & $1993-1997$ & $1997-2000$ \\
\hline Predicted change in log poverty & 0.42 & 0.40 & 0.11 & -0.45 \\
\hline Log(real income) & -0.16 & -0.71 & -0.55 & -0.65 \\
\hline Log(Gini) & 0.14 & 0.15 & 0.11 & 0.14 \\
\hline Log(saving rate) & -0.01 & 0.02 & 0.02 & 0.08 \\
\hline Log(food price index) & 0.28 & 0.61 & 0.30 & -0.25 \\
\hline $\log (\text { rmeh })^{(1)}$ & 0.12 & 0.27 & 0.20 & 0.18 \\
\hline Time trend & 0.05 & 0.04 & 0.05 & 0.04 \\
\hline Income & 1986-1990 & 1990-1993 & 1993-1997 & $1997-2000$ \\
\hline Predicted change in log poverty & 0.20 & 0.55 & 0.14 & -0.51 \\
\hline Log(real income) & -0.31 & -0.77 & -0.61 & -0.72 \\
\hline $\log (G i n i)$ & 0.23 & 0.28 & 0.23 & 0.29 \\
\hline Log(saving rate) & -0.01 & 0.00 & 0.01 & 0.02 \\
\hline Log(food price index) & 0.21 & 0.73 & 0.33 & -0.28 \\
\hline $\log (\text { rmeh })^{(1)}$ & 0.16 & 0.37 & 0.27 & 0.25 \\
\hline Time trend & -0.09 & -0.07 & -0.09 & -0.07 \\
\hline
\end{tabular}

Note: (1) rmeh is the budget share of medical, education, and housing expenditure. 
Figure 1 Poverty measures

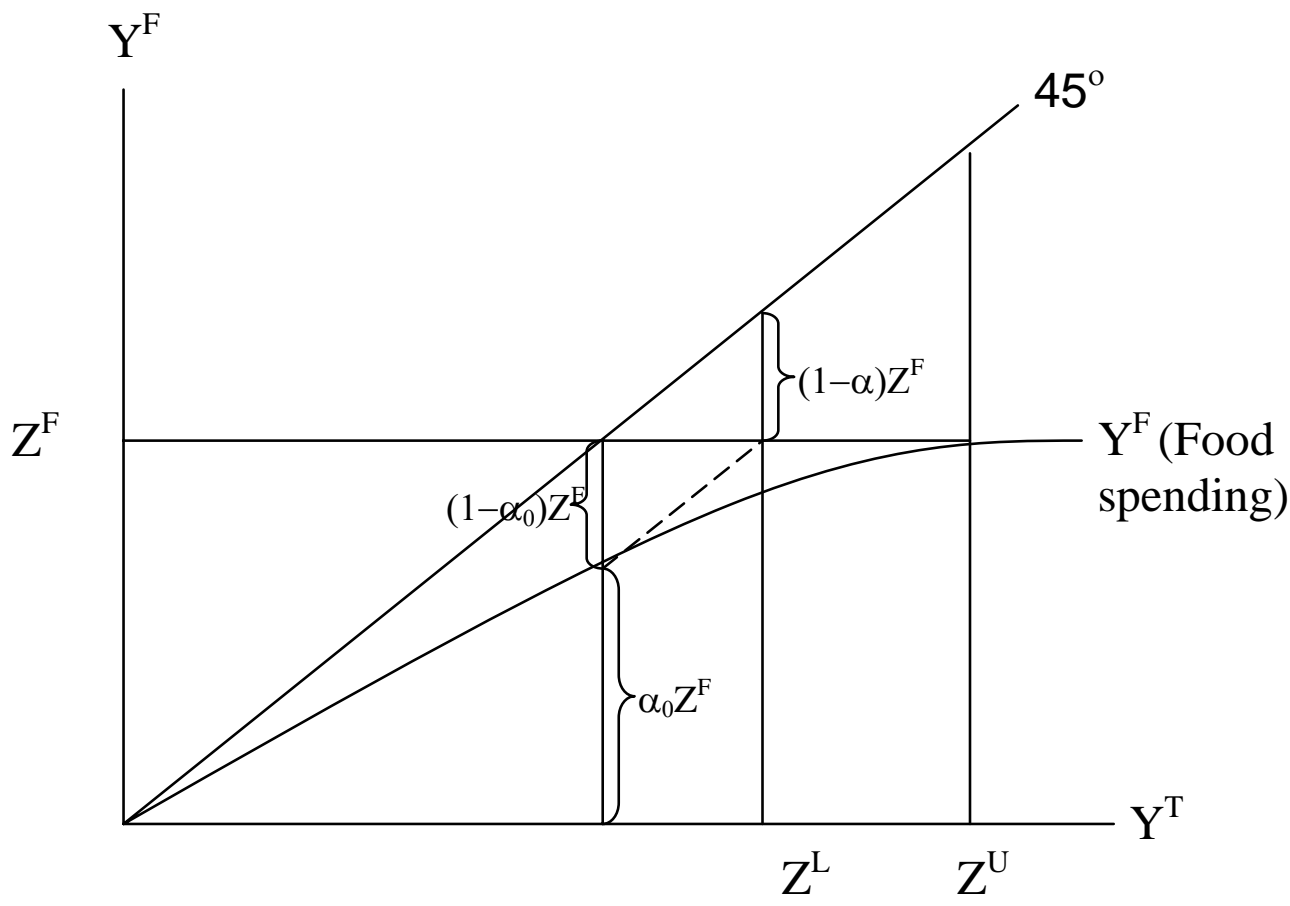

Figure 2 Education, medical and housing expenditure as proportion of total expenditure: 1986-2000

Mean income group

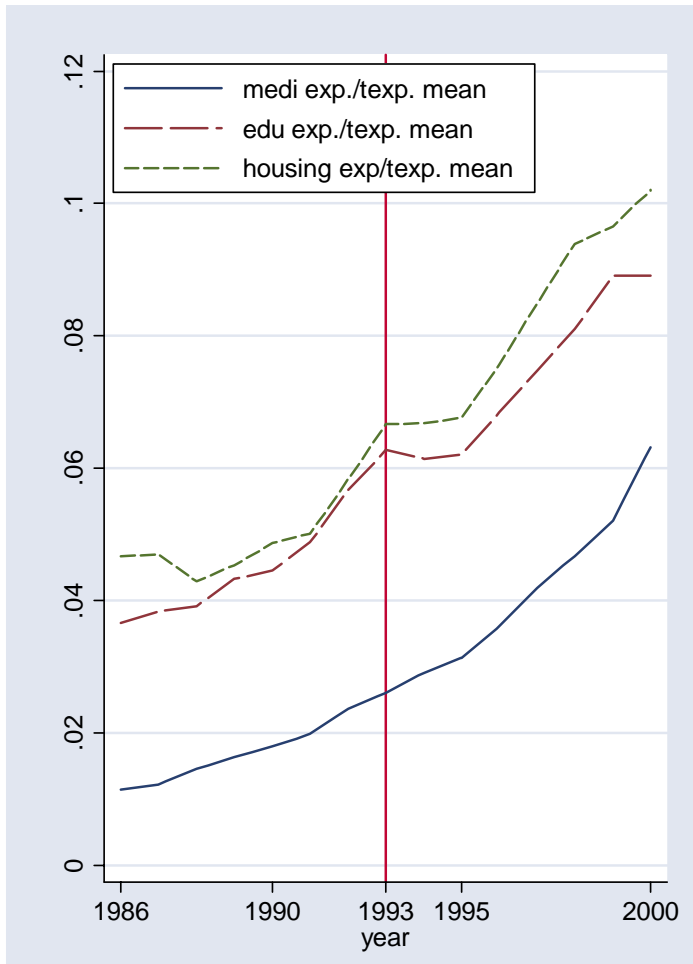

Bottom 30 percentiles

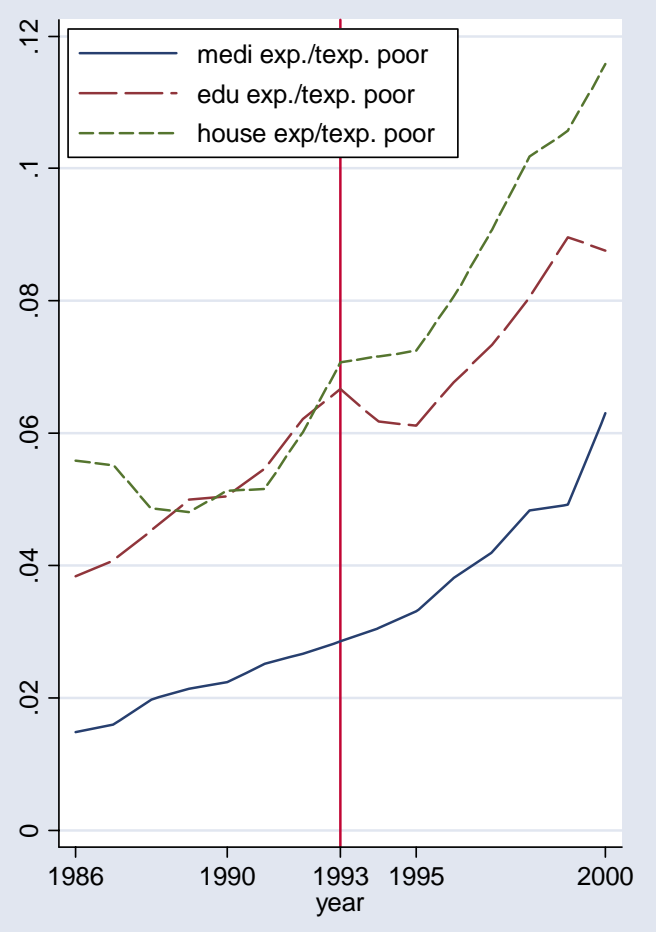


Table 3 Comparison of price indices and poverty indices

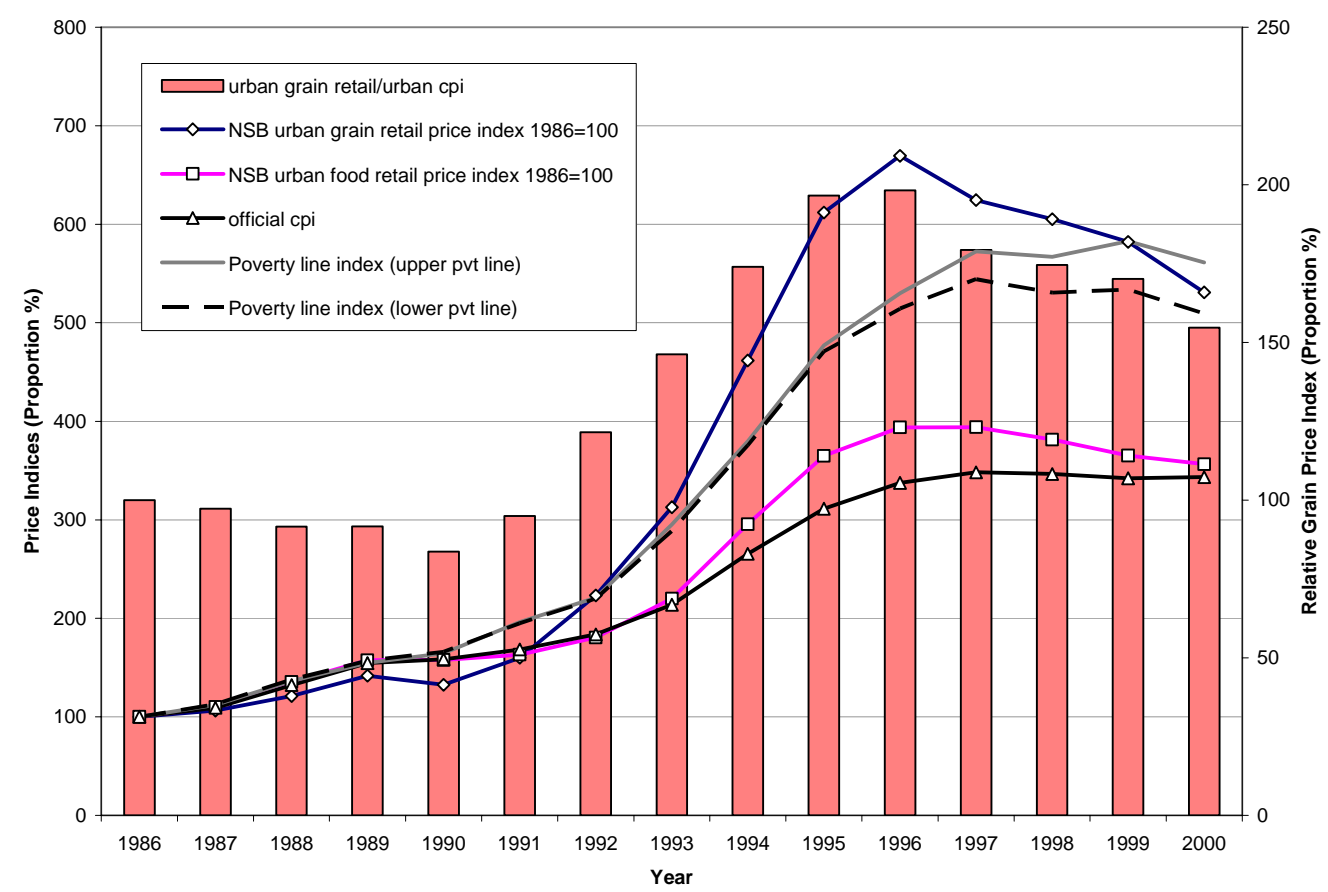

Sources: Poverty indices are calculated by dividing each year's average (across provinces) poverty lines by 1986 average poverty lines. NSB urban food and grain retail price indices: 1986-1994 data from China Statistical Yearbook 1994 table 8-6; 1995-2000 data from China Statistical Yearbooks, 1995-1997, table 8-4; 1998-2001 are from table 9-4 in each volume.

Figure 4 Food poverty line as proportion of upper poverty line: 1986-2000

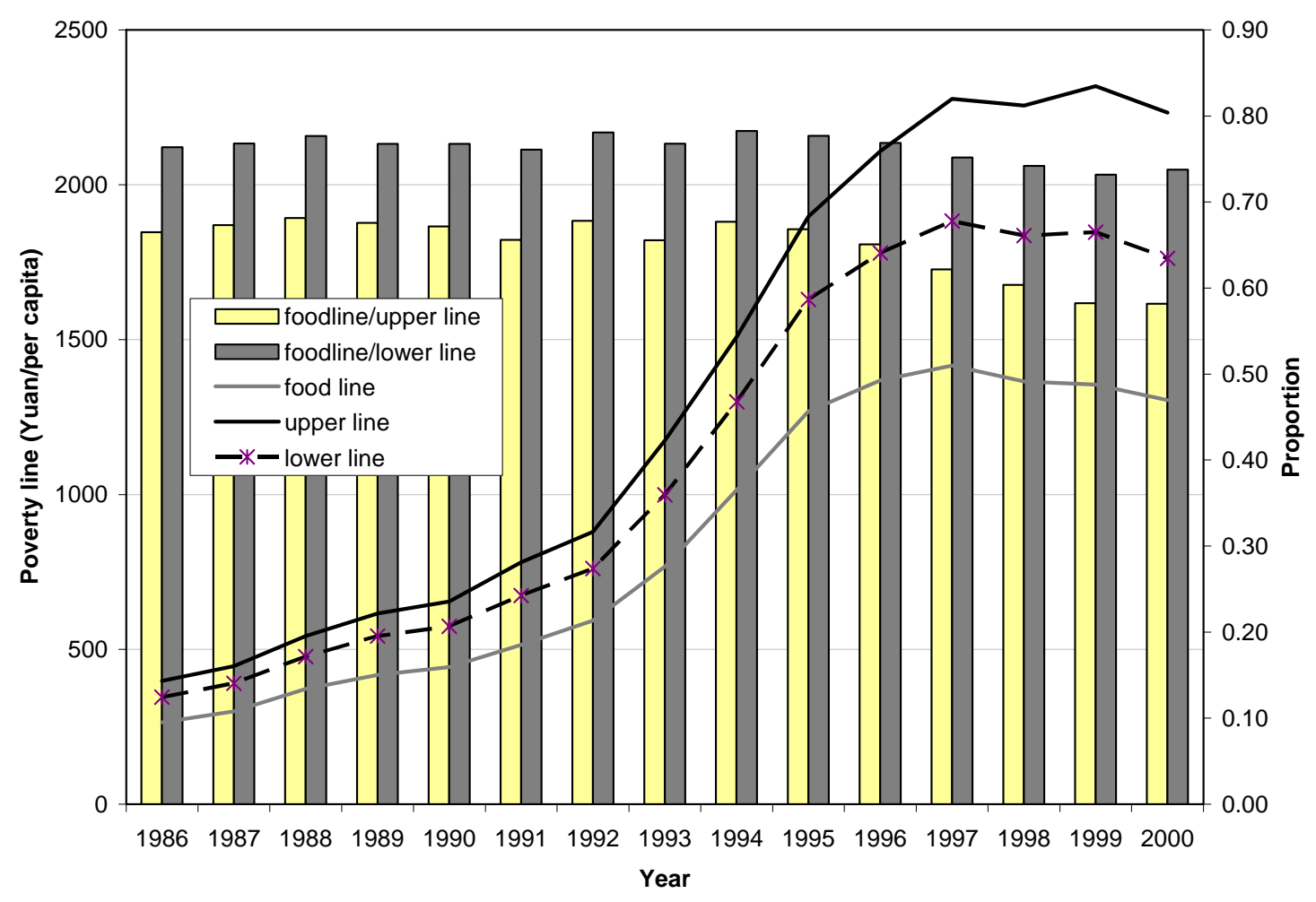


Figure 5 Poverty rate change at national level (upper and lower poverty lines): 1986-2000
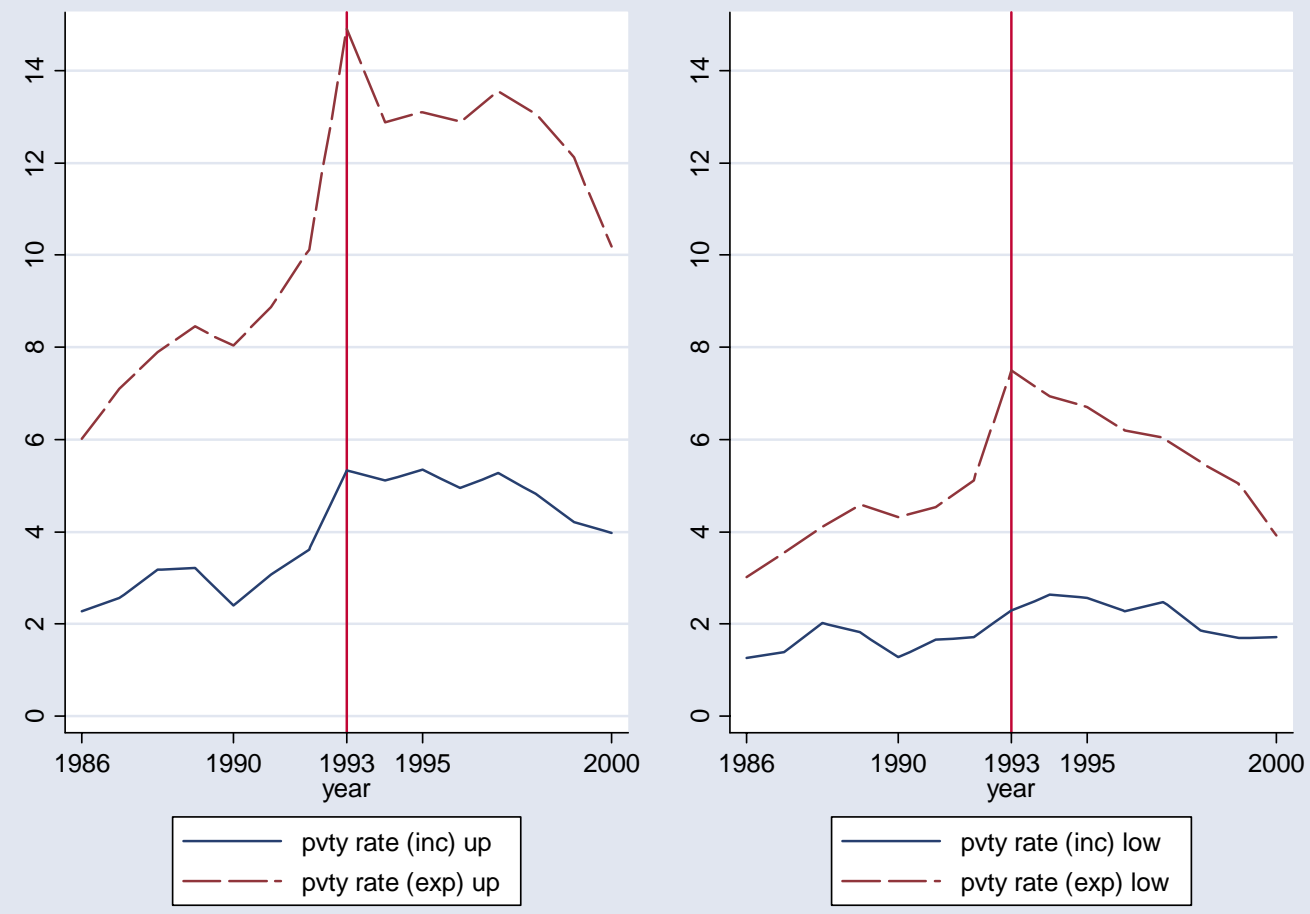

Figure 6 Change in income, expenditure and Gini coefficient: 1986-2000

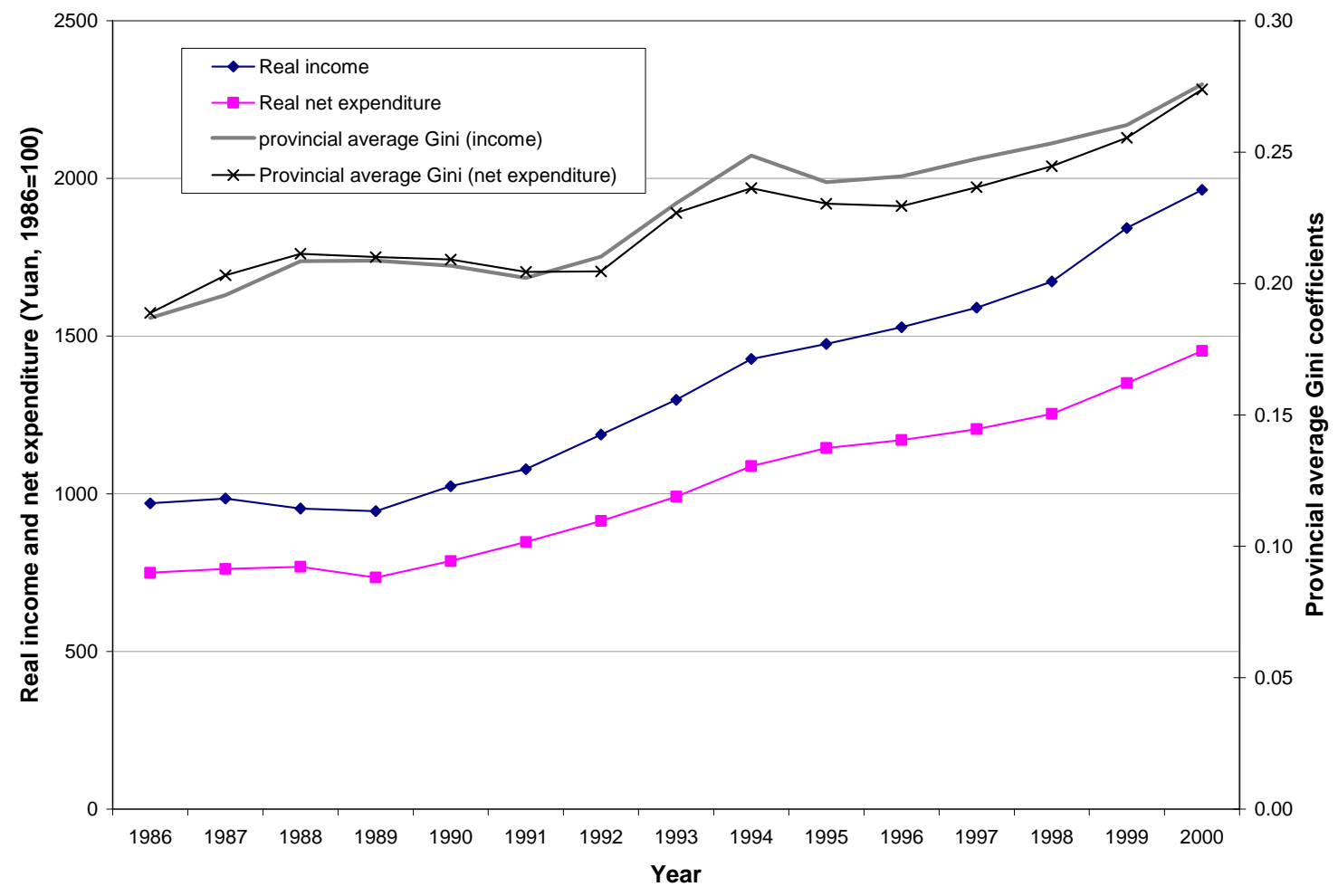


Figure 7 Decomposition of the change in log(poverty rate) measured in terms of expenditure

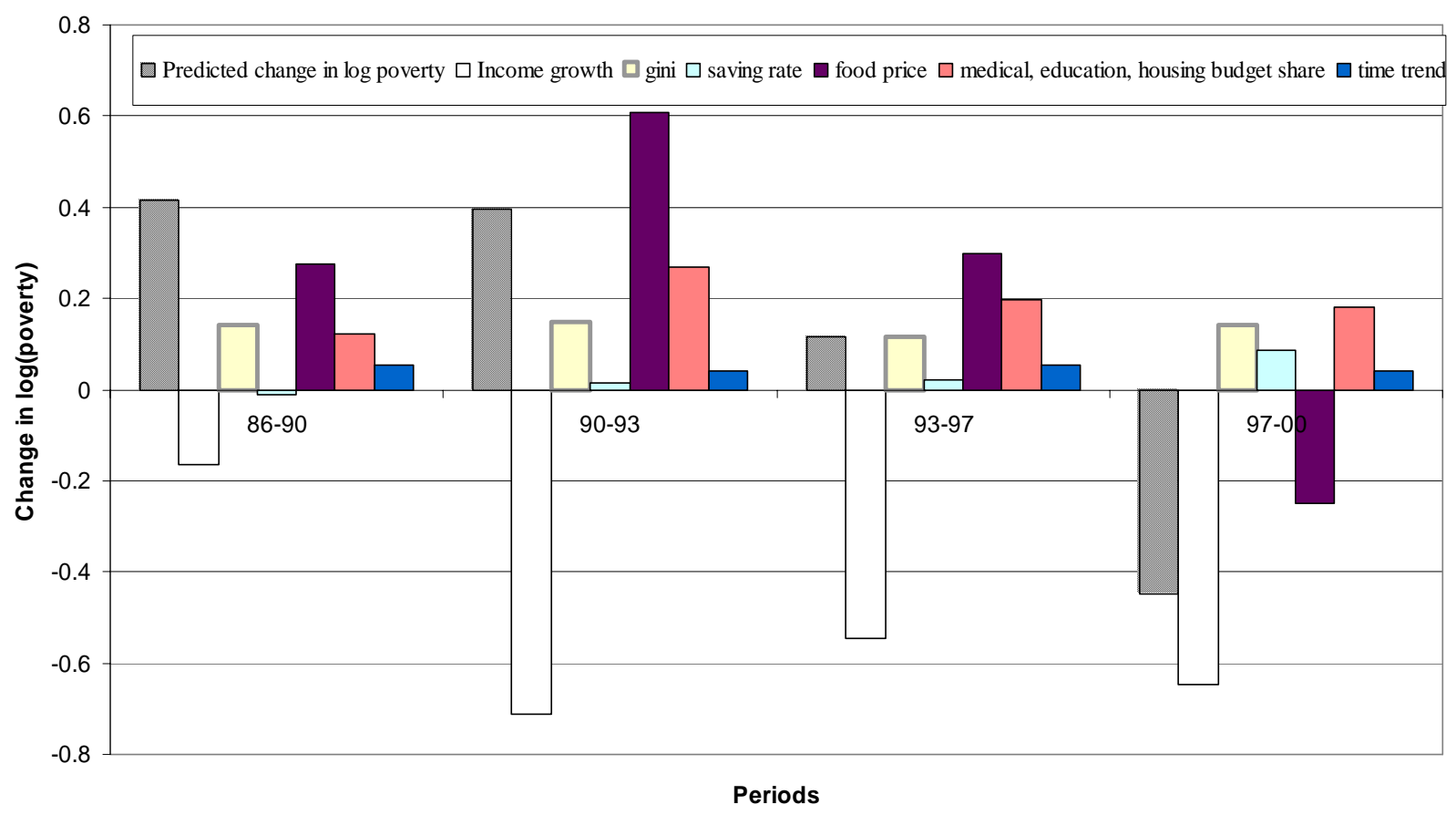




\section{Appendix A:}

Table A1 Sample size by year

\begin{tabular}{lcc}
\hline \hline & Number of households & Number of individuals \\
\cline { 2 - 3 } 1986 & 12,409 & 35,895 \\
1987 & 13,262 & 37,053 \\
1988 & 13,695 & 49,196 \\
1989 & 13,053 & 45,948 \\
1990 & 13,676 & 47,525 \\
1991 & 13,749 & 46,552 \\
1992 & 16,883 & 55,867 \\
1993 & 16,720 & 54,393 \\
1994 & 16,871 & 54,296 \\
1995 & 16,886 & 53,867 \\
1996 & 16,901 & 53,644 \\
1997 & 16,853 & 53,364 \\
1998 & 16,905 & 52,892 \\
1999 & 16,902 & 52,412 \\
2000 & 16,889 & 52,302 \\
Total & 231,654 & 745,206 \\
\hline \hline
\end{tabular}


Appendix B:

Table B1 Food poverty line (nominal price) by province, 1986-2000

\begin{tabular}{|c|c|c|c|c|c|c|c|c|c|c|c|c|c|c|c|}
\hline & 1986 & 987 & 1988 & 1989 & 1990 & 1991 & 1992 & 1993 & 1994 & 1995 & 1996 & 1997 & 1998 & 1999 & 2000 \\
\hline Beijing & 350 & 463 & 538 & 624 & 495 & 796 & 967 & 1186 & 1577 & 1943 & 2091 & 2009 & 1948 & 2042 & 2069 \\
\hline Tianjin & 343 & 378 & 422 & 477 & 513 & 632 & 755 & 990 & 1252 & 1531 & 1684 & 1681 & 1702 & 1756 & 1617 \\
\hline Hebei & 237 & 256 & 362 & 395 & 412 & 470 & 629 & 66 & .047 & 1311 & 1396 & 1397 & 329 & 330 & 122 \\
\hline Shanxi & 197 & 222 & 245 & 278 & 332 & 341 & & & & & & 30 & & 19 & 07 \\
\hline Neimengs & 229 & 235 & 268 & 300 & & & & & & & & & & 978 & \\
\hline Liaor & 307 & 336 & 420 & 483 & & & & & & & & & & & \\
\hline Jilin & 245 & 258 & 318 & 382 & 0 & 4 & & & 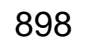 & & 21 & 59 & & 069 & 928 \\
\hline Heil & 265 & 299 & & & & & & & 810 & & & & & & 45 \\
\hline Shá & 3 & 10 & & & & & & & 78 & & & & & 294 & 2414 \\
\hline $\mathrm{Ji} \mathrm{a}$ & 291 & 28 & & & & & & & 05 & & & & & 377 & 1336 \\
\hline Zhe & 328 & 395 & 1 & 5 & & & & & 20 & 1718 & & 1952 & 1824 & 1738 & 1721 \\
\hline & 214 & 250 & 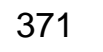 & 390 & & & & & & & 1326 & 1366 & 14 & 1273 & 1100 \\
\hline & 254 & 302 & 363 & 471 & 492 & 589 & & & 216 & & 1177 & 1573 & 1547 & 1550 & 1500 \\
\hline Jia & 211 & 209 & 321 & 353 & 371 & 413 & 494 & & 08 & 1132 & 1217 & 1152 & 1164 & 1114 & 1106 \\
\hline Sha & 297 & 319 & 402 & 485 & 496 & 552 & 673 & 82 & 1006 & 1297 & 1392 & 1412 & 1302 & 1363 & 1378 \\
\hline & 205 & 233 & 307 & 343 & 372 & 442 & 531 & 598 & 815 & 932 & 1110 & 1119 & 1078 & 1006 & 961 \\
\hline Hub & 247 & 286 & 316 & 374 & 400 & 485 & 504 & & & 1246 & 1339 & 1393 & 1345 & 1333 & 1297 \\
\hline Hur & 252 & 293 & 354 & 413 & 445 & 473 & 590 & & & 1257 & 1279 & 1323 & 1265 & 1305 & 1145 \\
\hline Gua & 376 & 444 & 592 & 575 & 765 & 900 & 1158 & 1443 & 1966 & 2215 & 2407 & 2392 & 2045 & 2299 & 2257 \\
\hline Guangxi & 271 & 330 & 420 & 397 & 632 & 651 & 701 & 965 & 1343 & 1658 & 1693 & 1639 & 1566 & 1523 & 1442 \\
\hline Hainan & & & & & 631 & 746 & 826 & 1104 & 1306 & 1635 & 1674 & 1722 & 1708 & 1597 & 1471 \\
\hline Sich & 20 & 290 & 328 & +1 & 415 & 478 & & & & 1212 & 1290 & 1346 & 1298 & 1252 & 1143 \\
\hline & 2 & 309 & 3 & 36 & & & & & & & & & 1339 & 1285 & 1165 \\
\hline & & 30 & 35 & & & & & & & & & & & & 46 \\
\hline & 20 & 248 & 288 & 33 & 34 & & & & & & & & & & 1064 \\
\hline & 28 & 278 & 27 & 32 & 33 & & & & & & & & 1113 & & 1182 \\
\hline & 243 & 218 & 277 & 351 & 320 & 36 & 26 & 32 & 51 & 65 & 69 & 1048 & 911 & 1048 & 1036 \\
\hline & 249 & 263 & 271 & 288 & 292 & 380 & 48 & 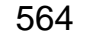 & . & 92 & 1026 & 1049 & 1073 & 986 & 1065 \\
\hline Xinjiang & 211 & 238 & 274 & 271 & 282 & 392 & 454 & 529 & 683 & 851 & 978 & 979 & 1067 & 1116 & 1069 \\
\hline
\end{tabular}


Table B2 Upper bound of poverty line (nominal price) by province: 1986-2000

\begin{tabular}{|c|c|c|c|c|c|c|c|c|c|c|c|c|c|c|c|}
\hline & 1986 & 1987 & 1988 & 1989 & 1990 & 1991 & 1992 & 1993 & 1994 & 1995 & 1996 & 1997 & 1998 & 1999 & 2000 \\
\hline Beijing & 538 & 750 & 817 & 951 & 728 & 1190 & 1515 & 1919 & 2423 & 2921 & 3223 & 3137 & 3068 & 3400 & 3499 \\
\hline Tianjin & 492 & 535 & 584 & 655 & 754 & 910 & 1087 & 1487 & 1929 & 2286 & 2627 & 2718 & 2958 & 3095 & 2773 \\
\hline Hebei & 396 & 416 & 555 & 631 & 695 & 833 & 1028 & 1332 & 1728 & 2270 & 2509 & 2548 & 2497 & 2565 & 1982 \\
\hline Shanxi & 299 & 329 & 389 & 448 & 545 & 522 & 533 & 895 & 569 & 1576 & 1672 & 1664 & 1601 & 1642 & 1733 \\
\hline Neimenggu & 358 & 353 & 417 & 454 & 398 & 542 & 438 & 518 & 580 & 812 & 825 & 1300 & 1783 & 1799 & 1716 \\
\hline Liaoning & 473 & 516 & 639 & 732 & 678 & 875 & 1147 & 1401 & 1680 & 1843 & 2091 & 2131 & 2183 & 2034 & 2002 \\
\hline Jilin & 376 & 391 & 521 & 598 & 595 & 747 & 971 & 1257 & 1464 & 1908 & 2053 & 1932 & 1904 & 1916 & 1712 \\
\hline Heilongji & 424 & 476 & 576 & 650 & 636 & 838 & 911 & 1167 & 1414 & 1742 & 1775 & 1886 & 1848 & 1661 & 1692 \\
\hline Shanghai & 536 & 591 & 708 & 899 & 1004 & 1022 & 1331 & 1773 & 2494 & 2929 & 3278 & 3563 & 3587 & 3607 & 3771 \\
\hline Jiangsu & 418 & 473 & 616 & 817 & 705 & 855 & 929 & 1211 & 1544 & 1953 & 2240 & 2389 & 2252 & 2203 & 2107 \\
\hline Zhejiang & 518 & 573 & 653 & 796 & 796 & 904 & 1176 & 1612 & 2183 & 2629 & 3091 & 3236 & 3046 & 3069 & 2813 \\
\hline Anhui & 289 & 345 & 520 & 510 & 565 & 718 & 595 & 904 & 1178 & 1639 & 1820 & 2050 & 2103 & 2138 & 1730 \\
\hline Fujian & 355 & 428 & 501 & 643 & 667 & 833 & 494 & 963 & 1640 & 1897 & 1586 & 2510 & 2439 & 2495 & 2640 \\
\hline Jiangxi & 303 & 288 & 456 & 506 & 534 & 590 & 691 & 898 & 1330 & 1587 & 1844 & 1797 & 1815 & 1841 & 1895 \\
\hline Shandong & 450 & 495 & 625 & 723 & 758 & 840 & 1097 & 1448 & 1807 & 2303 & 2563 & 2715 & 2552 & 2779 & 2868 \\
\hline Henan & 305 & 351 & 466 & 508 & 559 & 679 & 835 & 937 & 1264 & 1416 & 1811 & 1848 & 1899 & 1807 & 1857 \\
\hline Hubei & 383 & 430 & 467 & 557 & 609 & 761 & 734 & 1067 & 1517 & 1956 & 2133 & 2329 & 2258 & 2301 & 2221 \\
\hline Hunan & 359 & 405 & 503 & 574 & 640 & 711 & 845 & 1230 & 1430 & 1871 & 1977 & 2111 & 2133 & 2324 & 1863 \\
\hline Guangdong & 494 & 581 & 796 & 829 & 1066 & 1209 & 1630 & 1983 & 2753 & 3108 & 3424 & 3701 & 3121 & 3742 & 3598 \\
\hline Guangxi & 385 & 463 & 562 & 581 & 867 & 907 & 950 & 1372 & 1894 & 2353 & 2430 & 2520 & 2491 & 2436 & 2265 \\
\hline Hainan & & & & & 866 & 1048 & 1137 & 1484 & 1713 & 2191 & 2248 & 2411 & 2493 & 2436 & 2281 \\
\hline Sichuan & 404 & 423 & 487 & 593 & 612 & 740 & 744 & 1030 & 1366 & 1758 & 1976 & 2070 & 2099 & 2045 & 1830 \\
\hline Guizhou & 372 & 453 & 529 & 504 & 587 & 633 & 869 & 1127 & 1403 & 1837 & 2002 & 2047 & 2141 & 2204 & 1838 \\
\hline Yunnan & 302 & 448 & 521 & 645 & 622 & 702 & 467 & 1051 & 1064 & 1887 & 2309 & 2498 & 2314 & 2243 & 2177 \\
\hline Shaanxi & 328 & 394 & 455 & 509 & 558 & 632 & 774 & 1014 & 1310 & 1402 & 1757 & 2004 & 1967 & 2009 & 2004 \\
\hline Gansu & 450 & 433 & 430 & 481 & 499 & 607 & 671 & 807 & 1085 & 1256 & 1660 & 1868 & 1782 & 1954 & 2059 \\
\hline Qinghai & 391 & 328 & 412 & 546 & 478 & 545 & 378 & 426 & 694 & 963 & 1001 & 1712 & 1396 & 1777 & 1795 \\
\hline Ningxia & 379 & 417 & 448 & 461 & 481 & 601 & 833 & 978 & 1341 & 1482 & 1713 & 1871 & 2055 & 1848 & 2178 \\
\hline Xinjiang & 359 & 391 & 452 & 453 & 481 & 656 & 695 & 774 & 970 & 1265 & 1512 & 1469 & 1637 & 1854 & 1846 \\
\hline
\end{tabular}


Table B3 lower bound of poverty line (nominal price) by province: 1986-2000

\begin{tabular}{|c|c|c|c|c|c|c|c|c|c|c|c|c|c|c|c|}
\hline & 1986 & 1987 & 1988 & 1989 & 1990 & 1991 & 1992 & 1993 & 1994 & 1995 & 1996 & 1997 & 1998 & 1999 & 2000 \\
\hline Beijing & 465 & 632 & 695 & 831 & 639 & 1008 & 1272 & 1563 & 2016 & 2463 & 2678 & 2599 & 2534 & 2724 & 2760 \\
\hline Tianjin & 437 & 477 & 522 & 593 & 667 & 804 & 961 & 1291 & 1664 & 1978 & 2228 & 2252 & 2361 & 2452 & 2195 \\
\hline Hebei & 333 & 354 & 477 & 542 & 582 & 671 & 852 & 1069 & 1400 & 1803 & 1951 & 1969 & 1889 & 1898 & 1534 \\
\hline Shanxi & 258 & 287 & 329 & 377 & 452 & 446 & 460 & 743 & 506 & 1291 & 1372 & 1357 & 1292 & 1275 & 1285 \\
\hline Neimenggu & 304 & 306 & 353 & 391 & 344 & 449 & 370 & 443 & 527 & 719 & 732 & 1086 & 1379 & 1362 & 1290 \\
\hline Liaoning & 408 & 448 & 553 & 644 & 602 & 749 & 984 & 1151 & 1414 & 1555 & 1746 & 1759 & 1738 & 1620 & 1549 \\
\hline Jilin & 327 & 340 & 439 & 514 & 501 & 614 & 794 & 997 & 1199 & 1562 & 1642 & 1573 & 1505 & 1494 & 1301 \\
\hline Heilongji & 359 & 404 & 480 & 543 & 523 & 688 & 747 & 950 & 1177 & 1423 & 1435 & 1508 & 1459 & 1298 & 1306 \\
\hline Shanghai & 472 & 524 & 640 & 815 & 911 & 857 & 1190 & 1570 & 2211 & 2614 & 2876 & 3079 & 3058 & 3033 & 3142 \\
\hline Jiangsu & 367 & 417 & 545 & 729 & 632 & 750 & 817 & 1041 & 1364 & 1724 & 1945 & 2012 & 1900 & 1831 & 1752 \\
\hline Zhejiang & 442 & 504 & 583 & 708 & 704 & 796 & 997 & 1353 & 1838 & 2223 & 2555 & 2637 & 2475 & 2418 & 2285 \\
\hline Anhui & 262 & 311 & 467 & 469 & 510 & 640 & 545 & 805 & 1075 & 1457 & 1614 & 1752 & 1745 & 1744 & 1445 \\
\hline Fujian & 321 & 389 & 461 & 595 & 615 & 752 & 457 & 871 & 1485 & 1735 & 1453 & 2113 & 2063 & 2083 & 2100 \\
\hline Jiangxi & 268 & 260 & 407 & 455 & 477 & 522 & 611 & 782 & 1157 & 1404 & 1583 & 1522 & 1518 & 1489 & 1493 \\
\hline Shandong & 392 & 427 & 540 & 632 & 651 & 720 & 919 & 1151 & 1433 & 1821 & 1991 & 2043 & 1901 & 2017 & 2015 \\
\hline Henan & 266 & 306 & 405 & 447 & 490 & 585 & 709 & 790 & 1077 & 1213 & 1502 & 1512 & 1501 & 1402 & 1369 \\
\hline Hubei & 331 & 377 & 410 & 491 & 531 & 648 & 641 & 889 & 1265 & 1646 & 1775 & 1890 & 1817 & 1818 & 1750 \\
\hline Hunan & 320 & 366 & 448 & 513 & 566 & 614 & 734 & 1011 & 1226 & 1600 & 1665 & 1740 & 1715 & 1811 & 1510 \\
\hline Guangdong & 457 & 538 & 729 & 750 & 968 & 1098 & 1446 & 1769 & 2427 & 2745 & 2997 & 3125 & 2658 & 3058 & 2962 \\
\hline Guangxi & 345 & 420 & 514 & 521 & 785 & 809 & 852 & 1206 & 1658 & 2067 & 2112 & 2134 & 2074 & 2015 & 1867 \\
\hline Hainan & & & & & 784 & 949 & 1028 & 1360 & 1582 & 2013 & 2048 & 2149 & 2171 & 2075 & 1910 \\
\hline Sichuan & 348 & 372 & 426 & 529 & 537 & 633 & 656 & 900 & 1205 & 1536 & 1688 & 1755 & 1731 & 1677 & 1507 \\
\hline Guizhou & 321 & 397 & 470 & 455 & 519 & 565 & 761 & 969 & 1236 & 1595 & 1727 & 1742 & 1769 & 1752 & 1519 \\
\hline Yunnan & 267 & 393 & 455 & 562 & 551 & 604 & 432 & 911 & 956 & 1638 & 1940 & 2064 & 1923 & 1843 & 1767 \\
\hline Shaanxi & 279 & 334 & 385 & 437 & 470 & 530 & 652 & 827 & 1086 & 1187 & 1427 & 1566 & 1502 & 1511 & 1496 \\
\hline Gansu & 386 & 371 & 370 & 420 & 434 & 524 & 591 & 709 & 945 & 1101 & 1418 & 1557 & 1476 & 1560 & 1602 \\
\hline Qinghai & 327 & 288 & 360 & 475 & 419 & 476 & 336 & 391 & 627 & 844 & 881 & 1402 & 1173 & 1415 & 1407 \\
\hline Ningxia & 329 & 356 & 372 & 393 & 404 & 506 & 666 & 781 & 1073 & 1217 & 1374 & 1457 & 1545 & 1398 & 1551 \\
\hline Xinjiang & 293 & 325 & 377 & 379 & 393 & 541 & 588 & 674 & 848 & 1084 & 1267 & 1251 & 1369 & 1487 & 1441 \\
\hline
\end{tabular}


Appendix C: Provincial Poverty rates: 1986-2000
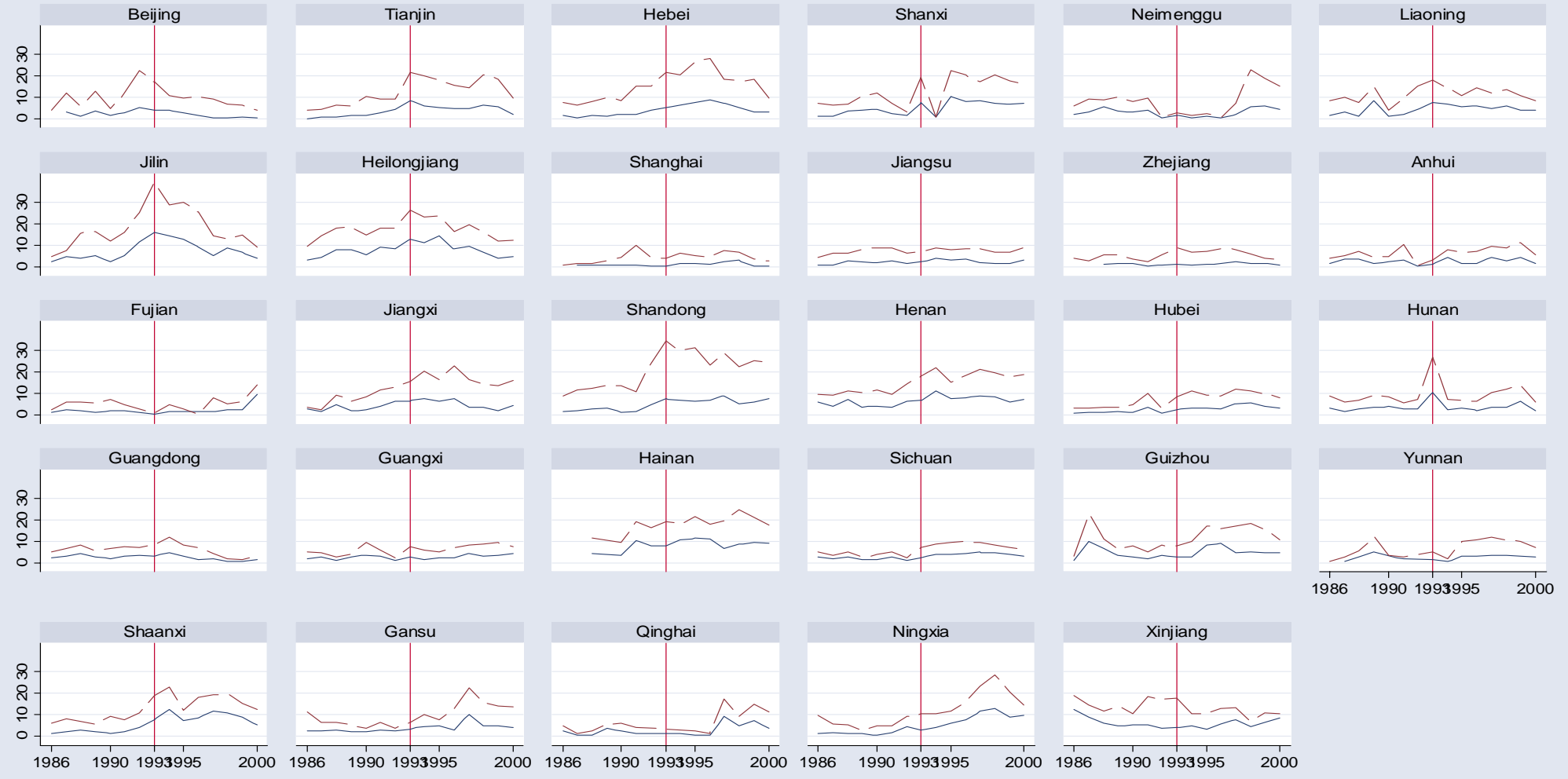

year

$$
\text { pvty rate (inc) up } \quad-\ldots \text { pvty rate (exp) up }
$$

Graphs by provinces 


\section{Appendix D: Change in income and income inequality by provinces}

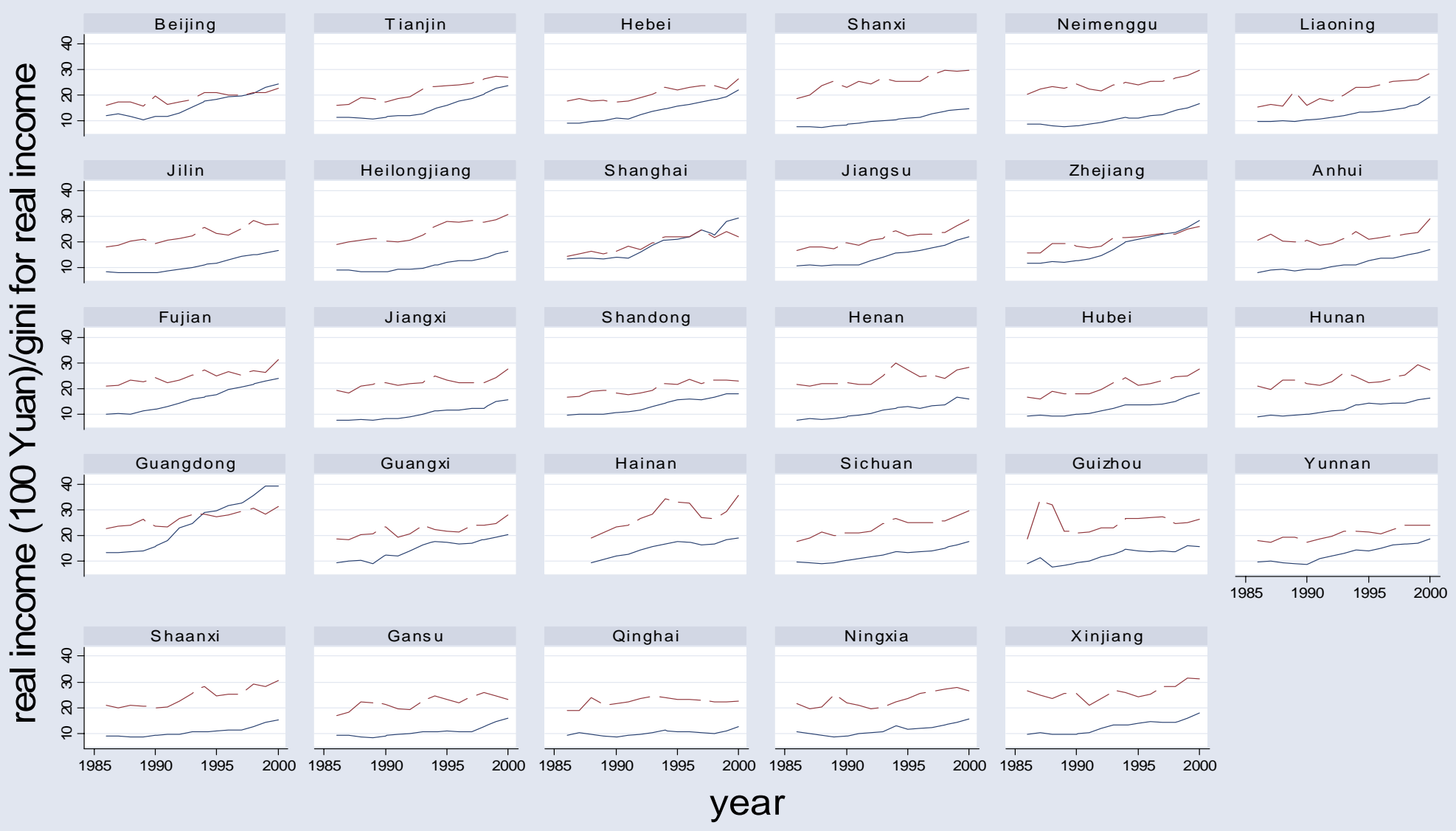

real income (100 Yuan) _ — - gini for real income

Graphs by provinces 